Article

\title{
Removal of Ionic Dyes by Nanofiber Membrane Functionalized with Chitosan and Egg White Proteins: Membrane Preparation and Adsorption Efficiency
}

\author{
Yue-Sheng Chen ${ }^{1,+}{ }^{\text {, Chien Wei Ooi }}{ }^{2,+}{ }^{+}$, Pau Loke Show ${ }^{3,+}$, Boon Chin Hoe ${ }^{2}$, Wai Siong Chai ${ }^{3}$, \\ Chen-Yaw Chiu ${ }^{1}$, Steven S.-S. Wang ${ }^{4, *}$ and Yu-Kaung Chang ${ }^{1, *}$
}

check for updates

Citation: Chen, Y.-S.; Ooi, C.W.; Show, P.L.; Hoe, B.C.; Chai, W.S.; Chiu, C.-Y.; Wang, S.S.-S.;

Chang, Y.-K. Removal of Ionic Dyes by Nanofiber Membrane Functionalized with Chitosan and Egg White Proteins: Membrane Preparation and Adsorption Efficiency. Membranes 2022, 12, 63. https://doi.org/10.3390/ membranes 12010063

Academic Editors: Mohammad Rezaul Karim and Akihiko Tanioka

Received: 30 October 2021

Accepted: 28 December 2021

Published: 1 January 2022

Publisher's Note: MDPI stays neutral with regard to jurisdictional claims in published maps and institutional affiliations.

Copyright: (c) 2022 by the authors. Licensee MDPI, Basel, Switzerland. This article is an open access article distributed under the terms and conditions of the Creative Commons Attribution (CC BY) license (https:// creativecommons.org/licenses/by/ $4.0 /)$.
1 Department of Chemical Engineering, Graduate School of Biochemical Engineering, Ming Chi University of Technology, New Taipei City 24301, Taiwan; a0955873266@o365.mcut.edu.tw (Y.-S.C.); chenyaw@gmail.com (C.-Y.C.)

2 Chemical Engineering Discipline and Advanced Engineering Platform, School of Engineering, Monash University Malaysia, Jalan Lagoon Selatan, Bandar Sunway 47500, Malaysia; ooi.chien.wei@monash.edu (C.W.O.); Hoe.BoonChin@monash.edu (B.C.H.)

3 Department of Chemical and Environmental Engineering, Faculty of Engineering, University of Nottingham Malaysia Campus, Jalan Broga, Semenyih 43500, Malaysia; Paul.oke.Show@nottingham.edu.my (P.L.S.); Cloudcws@gmail.com (W.S.C.)

4 Department of Chemical Engineering, National Taiwan University, Taipei 10617, Taiwan

* Correspondence: sswang@ntu.edu.tw (S.S.-S.W.); ykchang@mail.mcut.edu.tw (Y.-K.C.)

+ These authors contributed equally to this work.

\begin{abstract}
Electrospun polyacrylonitrile (PAN) nanofiber membrane was functionalized with chitosan and proteins for use in the treatment of dye-containing wastewater. The PAN nanofiber membrane was subjected to alkaline hydrolysis, before being grafted with chitosan and subsequently the proteins from chicken egg white. The resultant nanofiber membrane (P-COOH-CS-CEW) was comprehensively characterized using thermogravimetric analysis, Fourier-transform infrared spectroscopy, and scanning electron microscopy. The efficiency of $\mathrm{P}-\mathrm{COOH}-\mathrm{CS}-\mathrm{CEW}$ in removing cationic dye toluidine blue $\mathrm{O}$ (TBO) and anionic dye acid orange 7 (AO7) in aqueous solution was evaluated. Based on the performance of model fitting, Langmuir and pseudo-second-order kinetic model could be used to describe the performance of P-COOH-CS-CEW in the removal of TBO (pH 10) and AO7 ( $\mathrm{pH}$ 2) from the dye solutions. The adsorbed TBO and AO7 dyes can be completely desorbed by an elution solution made of $50 \%(\mathrm{v} / \mathrm{v})$ ethanol and $1 \mathrm{M}$ sodium chloride. After five consecutive adsorption-desorption cycles, the efficiency of dye removal by P-COOH-CS-CEW was maintained above $97 \%$.
\end{abstract}

Keywords: protein modified nanofiber membrane; chitosan; egg white proteins; removal; cationic and anionic dyes

\section{Introduction}

The dye-contaminated wastewater produced from textile, papermaking, printing, and related industries can cause significant environmental issues [1,2]. Due to the complex and robust chemical structures, dyes are very stable in water and are resistant to degradation by light, chemical, or biological treatment. Therefore, removing the dyes using traditional treatment of wastewater can be challenging [3]. The conventional methods used in the dye removal process include biological treatment, coagulation/flocculation, ozone treatment, chemical oxidation, membrane filtration, photocatalytic degradation, and adsorption [4-9]. However, these methods are energy-demanding and involve multiple operations, thereby limiting their wide adoption in industrial applications [2]. Adsorption is a popular approach to dye wastewater treatment due to its cost-effectiveness and simplicity of operation [10-15]. Sugar cane bagasse, cotton waste, chitin, chitosan, peat, 
microorganisms (fungus and yeasts), maize cob [16], hazelnut shell, saw dust (derived from walnut, cherry, oak, pitch pine, and pine), cane pitch [17], soy meal hull, banana pitch, Brazilian pine-fruit shell [18,19], and rice husk [20], aqai stalks [21] have all been widely used as adsorbent for dye removal.

Nanofibers are a promising adsorber because of their high ratio of surface area to weight, good flexibility, high porosity, superior mechanical properties and water permeability, and the easiness of surface modification [22-27]. These nanofibers were successfully used in the filtration processes (dye removal) that could treat a large amount of wastewater in a short time [22,28-32]. Polyacrylonitrile (PAN) yarn is an inexpensive polymer that can be electrospun into nanofibers. PAN nanofiber membrane is known to possess strong mechanical strength and high chemical stability. Moreover, the nitrile groups $(-\mathrm{CN})$ in PAN nanofibers could be converted carboxyl groups $(-\mathrm{COOH})$ via alkaline hydrolysis and acid neutralization. The - $\mathrm{COOH}$ groups on the surface of acidic PAN nanofiber membrane $(\mathrm{P}-\mathrm{COOH})$ serve as the sites for the coupling of other functional molecules, such as chitosan. Chitosan is an excellent bio-adsorbent with amino and/or hydroxyl groups that act as the active adsorption sites for capturing cationic and/or anionic dyes [33,34]. Hence, the coupling of chitosan on the $\mathrm{P}-\mathrm{COOH}$ will boost the functionality of the resultant nanofiber membrane (P-COOH-CS) for the treatment of dye-containing wastewater.

The adsorption capacity of chitosan-derived adsorbents could be improved by functionalization using cross-linking reagents or incorporation of functional groups onto its chitosan backbone [35]. Proteins are a promising functional group that can be coupled to the chitosan backbone or $\mathrm{P}-\mathrm{COOH}$. The amino $\left(-\mathrm{NH}_{2}\right)$ and $-\mathrm{COOH}$ groups in protein can be easily coupled to either the $-\mathrm{NH}_{2}$ group on $\mathrm{P}-\mathrm{COOH}-\mathrm{CS}$ or $-\mathrm{COOH}$ group on $\mathrm{P}-\mathrm{COOH}$ to form P-COOH-CS-CEW and P-COOH-CEW, respectively. Depending on the availability of positively and negatively charged groups, $\mathrm{P}-\mathrm{COOH}-\mathrm{CS}-\mathrm{CEW}$ can treat waste products with positive or negative charge, such as heavy metal ions, cationic or anionic dyes in wastewater. Overdue egg white waste can be a good source of proteins for the functionalization of $\mathrm{P}-\mathrm{COOH}-\mathrm{CS}$. Chicken egg white (CEW) is often used as a source of lysozyme in the studies of protein purification [36-38]. Aside from lysozyme, CEW contains other proteins such as ovalbumin (54\%), ovotransferrin (12\%), and ovomucin (11\%) [39].

Acid Orange 7 (AO7) and Toluidine Blue $\mathrm{O}$ (TBO) dye are widely used as a mediator for various biochemical reactions as well as a coloring agent for fabrics [10]. To the best of our knowledge, there is no relevant report demonstrating the application of $\mathrm{P}-\mathrm{COOH}-$ CS-CEW for the removal of AO7 and TBO dyes from aqueous solutions. This study aims to synthesize and discover the potential of a promising protein-functionalized nanofiber membrane in dye removal (AO7 and TBO). P-COOH-CS-CEW was characterized using thermogravimetric analysis (TGA), Fourier-transform infrared (FTIR) spectroscopy, and scanning electron microscope (SEM) analyses. Moreover, the adsorption isotherms and kinetics parameters were investigated. The effects of operating parameters (i.e., initial $\mathrm{pH}$ and contact time) on the performance of AO7 and TBO adsorption were also investigated. In addition, equilibrium isotherm and kinetic binding mechanism, dye desorption, and reusability of $\mathrm{P}-\mathrm{COOH}-\mathrm{CS}-\mathrm{CEW}$ were studied.

\section{Materials and Methods}

\subsection{Materials}

PAN yarn (Mw: 120,000, 93\% acrylonitrile, 7\% vinyl acetate) and polyethylene terephthalate (PET) were supplied by Fortune Industries Inc. (New Taipei City, Taiwan), while spunbond fabric (basis weight $15 \mathrm{~g} / \mathrm{m}^{2}$, thickness $90 \mu \mathrm{m}$, fiber diameter 300-500 $\mu \mathrm{m}$ ) was purchased from Freudenberg Far Eastern Spunweb Co., Ltd. (New Taipei City, Taiwan). CEW, TBO (Mw: $305.83 \mathrm{~g} / \mathrm{mol})$, AO7 (Mw: $350.32 \mathrm{~g} / \mathrm{mol})$, 4-morpholineethanesulfonic acid (MES), 1-ethyl-3-(3-dimethylaminopropyl) carbodiimide (EDC) and N-hydroxysuccinimide (NHS) were bought from Sigma-Aldrich (St. Louis, MO, USA). Chitosan (Mw: 50,000 g/mol) was acquired from Chengli Industrial Co., Ltd. (New Taipei City, Taiwan). Electrospinning equipment was purchased from Falco Enterprise Co., Ltd. (New Taipei City, Taiwan). 


\subsection{Preparation and Modification of PAN Nanofiber Membranes}

A syringe with no. 21 stainless steel nozzle was filled with $10 \mathrm{~mL}$ of PAN solution. The PAN solution was prepared by dissolving $1.5 \mathrm{~g}$ of PAN yarn in $10 \mathrm{~mL}$ of dimethylacetamide (DMAc) at $100{ }^{\circ} \mathrm{C}$. The PAN solution was ejected from the syringe to form nanofibers on a grounded stainless-steel roller pre-wrapped with non-woven PET. The electrospinning process was run for $10 \mathrm{~h}$ and the operating conditions were based on the methodology reported previously [38]. The resultant PAN nanofiber membrane was then hot-pressed at $100{ }^{\circ} \mathrm{C}$ for $1 \mathrm{~h}$. A heat-pressing treatment enhances the adherence of the nanofiber layer to the PET supporting matrix, and results in a more uniform pore size distribution and a smaller pore size.

Next, the alkaline hydrolysis of PAN nanofiber membrane (25 mm diameter) was conducted in $5 \mathrm{~mL}$ of $\mathrm{NaOH}$ solution $(3 \mathrm{M})$ at $80^{\circ} \mathrm{C}$ for $18 \mathrm{~min}$. The excess $\mathrm{NaOH}$ in the hydrolyzed nanofiber membrane was subsequently removed by water washing. Later, the membrane was treated with $0.1 \mathrm{M}$ of $\mathrm{HCl}$ to generate the ion-exchange PAN nanofiber membrane, which was abbreviated as $\mathrm{P}-\mathrm{COOH}$. The surface density of the carboxyl groups on the $\mathrm{P}-\mathrm{COOH}$ was determined using TBO dye interaction at $\mathrm{pH} 10$ [40].

Next, a piece of carboxylated PAN nanofiber membrane $(\mathrm{P}-\mathrm{COOH})$ was submerged into $5 \mathrm{~mL}$ of MES hydrate solution $(0.1 \mathrm{M}, \mathrm{pH}$ ) containing EDC (300 $\mu \mathrm{mol})$, NHS $(300 \mu \mathrm{mol})$, and chitosan $(1 \mathrm{mg} / \mathrm{mL})$. The shaking incubation of the membrane was set at $100 \mathrm{rpm}$ and $25^{\circ} \mathrm{C}$ for $3 \mathrm{~h}$. Finally, the chitosan-coupled P-COOH (labelled as P-COOH-CS) was rinsed with distilled water to eliminate any remaining chitosan. The clean $\mathrm{P}-\mathrm{COOH}-\mathrm{CS}$ was dried in an oven at $60{ }^{\circ} \mathrm{C}$. The density of amino groups on the surface of P-COOH-CS was determined using an established protocol reported elsewhere [32].

To couple proteins on $\mathrm{P}-\mathrm{COOH}-\mathrm{CS}$, a piece of $\mathrm{P}-\mathrm{COOH}-\mathrm{CS}(\sim 0.03 \mathrm{~g})$ was first immersed in $5 \mathrm{~mL}$ of MES buffer solution (pH 5, $0.1 \mathrm{M}$ ) containing $300 \mu \mathrm{mol} \mathrm{EDC,} 300 \mu \mathrm{mol} \mathrm{NHS}$, and $5 \mathrm{mg}$ CEW. The nanofiber membrane was reacted in the solution for $3 \mathrm{~h}$ at $100 \mathrm{rpm}, 25^{\circ} \mathrm{C}$, followed by the washing with water and the drying in oven at $60{ }^{\circ} \mathrm{C}$. The synthesized nanofiber membrane was designated as PCOOH-CS-CEW. Figure 1 shows the synthesis routes of carboxylated PAN nanofiber membranes (P-COOH-CS and P-COOH-CS-CEW).

\subsection{Characterization of Nanofiber Membranes}

The morphology and diameter of nanofiber mats were observed using a SEM (S2600H/EDX, Hitachi, Tokyo, Japan). Before the imaging, all samples were sputter-coated with platinum. The FTIR spectra of samples were acquired using FTIR spectrophotometer (Spectrum One 55366, Perkin Elmer, Akron, OH, USA) with a resolution of $1 \mathrm{~cm}^{-1}$ over the wavenumber range of $400-4000 \mathrm{~cm}^{-1}$. TGA was carried out using a thermogravimetric analyzer (TGA Q600, Mettle Toledo, Columbus, $\mathrm{OH}$, USA) at a heating rate of $20^{\circ} \mathrm{C} / \mathrm{min}$ under nitrogen purging.

The concentrations of AO7 and TBO dyes in the solution were determined using a UVVis spectrophotometer (Ultrospec 3100 Pro, GE Healthcare Biosciences, Uppsala, Sweden) at $485 \mathrm{~nm}$ and $633 \mathrm{~nm}$, respectively [2,41]. The negatively charged AO7 dye interacted with the positively charged surface functional group $\left(-\mathrm{NH}_{3}{ }^{+}\right)$, while the positively charged TBO dye reacted with the negative surface ions $\left(-\mathrm{COO}^{-}\right)$. Both reactions occurred at a stoichiometric ratio of 1:1 $[37,38]$. The contents of amine and carboxylic group in the nanofiber membranes were then determined. The mechanical properties of the PAN and P-COOH-CS-CEW nanofiber membranes were determined at room temperature using a universal test machine (Tinius Olsen H1KS, SDL ATLAS, Rock Hill, SC, USA). The extension rate of the test was set to $10 \mathrm{~mm} / \mathrm{min}$. From the stress-strain curves, the averages of ultimate tensile strength (TS, MPa) Young's modulus (YM, MPa), and elongation at break $(E B, \%)$ were determined. 
(a)

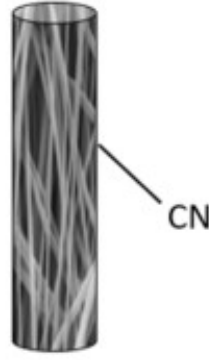

PAN
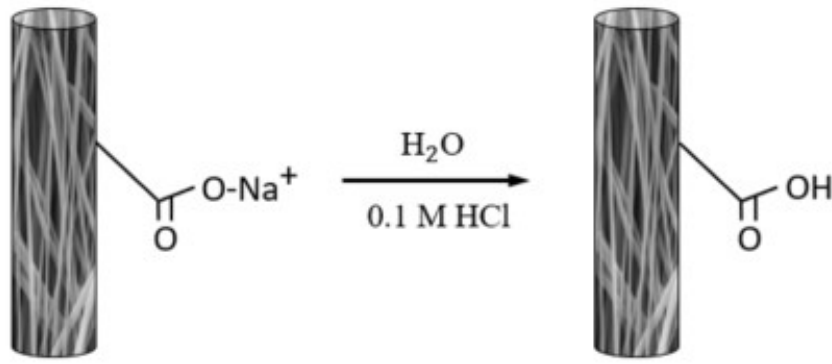

$\mathrm{P}-\mathrm{COOH}$

(b)

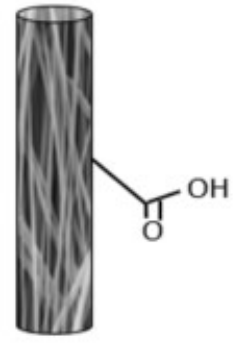

$\mathrm{P}-\mathrm{COOH}$

(c)
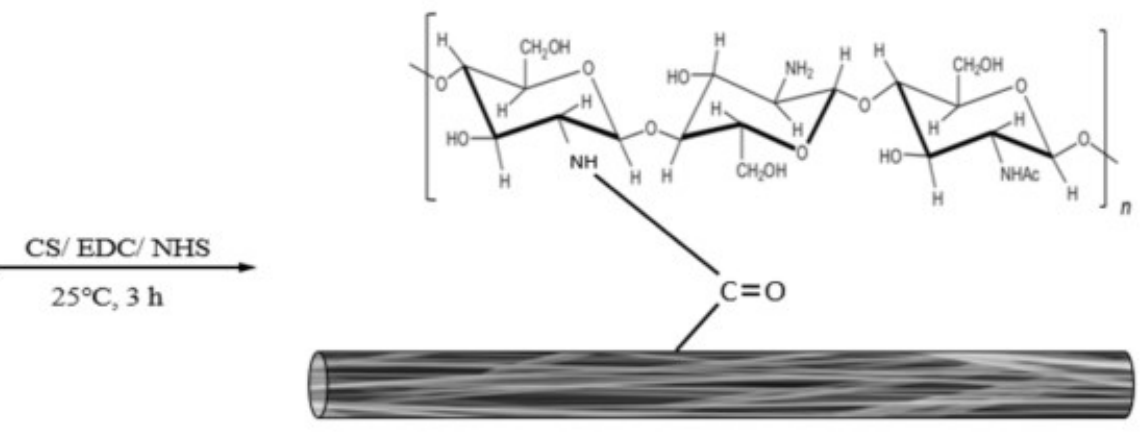

P-COOH-CS

c)

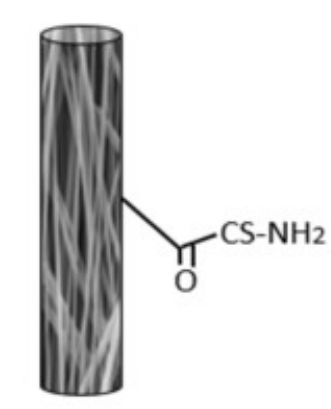

P-COOH-CS

\section{CEW/ EDC/ NHS \\ $25^{\circ} \mathrm{C}, 3 \mathrm{~h}$}

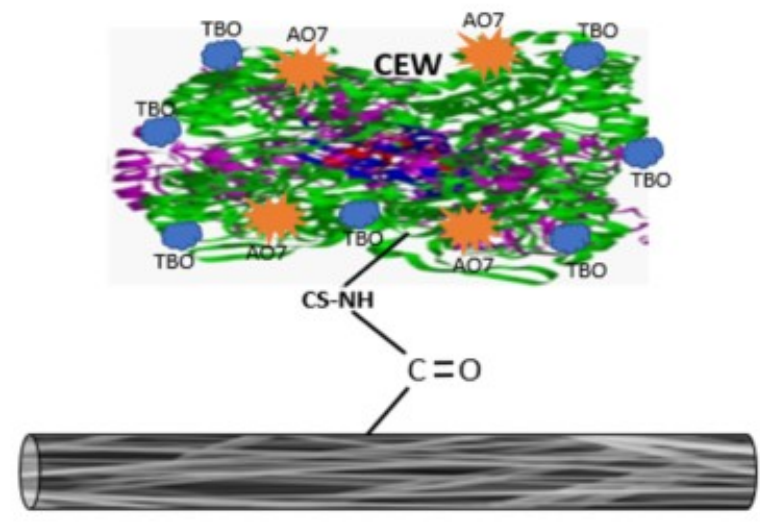

P-COOH-CS-CEW

Figure 1. Preparation and modification of PAN nanofiber membranes: (a) P-COOH, (b) P-COOH-CS, and (c) P-COOH-CS-CEW.

\subsection{Effect of Operating Parameters on the Adsorption of Dye Molecules}

Similar procedures have been reported for coupling $\mathrm{pH}$ and concentration of CEW on the membranes [42,43]. The effects of coupling $\mathrm{pH}$ and loaded amount of CEW in the reaction solution on the immobilized density of CEW were investigated. Moreover, the performance of the P-COOH-CS-CEW nanofiber membrane for adsorption of AO7 and TBO dyes was investigated under different $\mathrm{pH}$ conditions $[42,43]$. 


\subsection{Equilibrium Isotherm and Kinetic of Dye Adsorption}

In the isothermal adsorption studies, $\mathrm{P}-\mathrm{COOH}-\mathrm{CS}-\mathrm{CEW}$ nanofiber membranes were first incubated in $50 \mathrm{~mL}$ flasks containing dye solutions with different concentrations of $\mathrm{AO} 7(\mathrm{pH} 2)$ or TBO $(\mathrm{pH} 10)$. The nanofiber membranes and dye solutions were mixed at $150 \mathrm{rpm}$ and $25^{\circ} \mathrm{C}$. After $3 \mathrm{~h}$, the residual concentration of dye in the aqueous solution was measured. Then, the equilibrium binding capacity of nanofiber membrane (mg dye/g) was determined. The kinetic of dye adsorption was evaluated using P-COOH-CS-CEW incubated in dye solution $\left(1-3 \mathrm{mg} / \mathrm{mL}\right.$ of dye) at $100 \mathrm{rpm}$ and $25^{\circ} \mathrm{C}$ for a period of $0-3 \mathrm{~h}$.

\subsection{Desorption Studies}

A piece of P-COOH-CS-CEW (i.d. $25 \mathrm{~mm}, \sim 0.03 \mathrm{~g}$ ) and $5 \mathrm{~mL}$ of dye solution (AO7 or $\mathrm{TBO} ; 3 \mathrm{mg} / \mathrm{mL}$ ) were added to a $50-\mathrm{mL}$ flask. The adsorption process was performed at $25^{\circ} \mathrm{C}$ and $150 \mathrm{rpm}$ for $2 \mathrm{~h}$. After that, the membrane was removed from the dye solution and was subjected to washing by buffer solution ( $\mathrm{pH} 2$ for AO7, or $\mathrm{pH} 10$ for TBO) to remove the residual and unbound dyes on the membrane. Next, the desorption process was conducted at $150 \mathrm{rpm}$ for $2 \mathrm{~h}$ using various types of eluents $(5 \mathrm{~mL})$, including $1 \mathrm{M}$ of salts [sodium chloride $(\mathrm{NaCl})$, ammonium sulfate $\left(\mathrm{NH}_{4}\right)_{2} \mathrm{SO}_{4}$, or potassium thiocyanate (KSCN)] dissolved in $50 \%$ organic solvents (ethanol, ethylene, or glycerol). The amounts of eluted dyes in the solution before and after the desorption were recorded. Later, the dye-desorption efficiency was calculated by dividing the amount of desorbed dye by the amount of dye adsorbed on the P-COOH-CS-CEW. In every adsorption-desorption cycle, the adsorption capacity of P-COOH-CS-CEW for the dyes and the elution efficiency (\%) were calculated.

\section{Results and Discussion}

\subsection{Characterization of Nanofiber Membranes}

Figure 2 displays the FTIR spectra of PAN and the modified nanofiber membranes, in which the peaks were observed at $2927 \mathrm{~cm}^{-1}$ (C-H bond), $2253 \mathrm{~cm}^{-1}$ (-C $\equiv \mathrm{N}$ bond), $1735 \mathrm{~cm}^{-1}$ (-C=O bond), and $1452 \mathrm{~cm}^{-1}$ (bending vibration of $\mathrm{C}-\mathrm{H}$ bond) [44]. The prominent peak at $1690 \mathrm{~cm}^{-1}(-\mathrm{C}=\mathrm{O})$ as shown in the FTIR spectrum of $\mathrm{P}-\mathrm{COOH}$ indicates the presence of the carbonyl group. In $\mathrm{P}-\mathrm{COOH}-\mathrm{CS}$, the existence of amide functional group was proven by the presence of a prominent peak at $1245 \mathrm{~cm}^{-1}$. P-COOH-CS-CEW's FTIR spectra showed peaks at $1653 \mathrm{~cm}^{-1}$ (Amide I), $1540 \mathrm{~cm}^{-1}$ (Amide II), and $1245 \mathrm{~cm}^{-1}$ (Amide III), which are associated with amide vibration [14] and C-O vibration $\left(1330-1050 \mathrm{~cm}^{-1}\right)$. The presence of $\mathrm{C}-\mathrm{H}$ and $\mathrm{C}-\mathrm{OH}$ bonds was proven by the peaks $\left(500-1000 \mathrm{~cm}^{-1}\right)$.

The shapes and structures of nanofiber membranes (PAN, P-COOH, P-COOH-CS, and P-COOH-CS-CEW) are shown in the SEM images (Figure 3). For all the fabricated nanofiber membranes, the nanofibers were randomly oriented and in the size range of 400-600 nm. The P-COOH film contained a rough structure. After the surface modification of P-COOH with chitosan and CEW, the thickness of nanofibers of P-COOH-CS-CEW increased marginally. Nevertheless, no obvious change in the overall nanofiber shape was observed. In addition, the surface of the nanofiber membrane modified with CEW protein is partially opaque, showing the presence of charge.

TGA curves of nanofiber membranes are shown in Figure 4 a. At $100^{\circ} \mathrm{C}$, a slight weight loss was observed owing to the loss of moisture from the nanofiber membrane. At around $300{ }^{\circ} \mathrm{C}$, these four types of nanofiber membranes exhibited different degrees of weight loss. From $300{ }^{\circ} \mathrm{C}$ to $600{ }^{\circ} \mathrm{C}$, the percentages of weight loss in P-COOH, P-COOH-CS-CEW, PAN, and P-COOH-CS nanofiber membranes are $48.73 \%, 40.86 \%, 38.92 \%$, and $37.50 \%$, respectively. A higher weight loss was detected in P-COOH-CS-CEW because the thermal stability of the three-dimensional protein-modified nanofiber membrane is weaker.

The mechanical properties (TS, YM, and EB) of the PAN and P-COOH-CS-CEW nanofiber membranes are shown in Figure $4 \mathrm{~b}$. The results showed that the mechanical properties of the PAN-COOH-CS-CEW nanofiber membrane are worse than that of the PAN nanofiber membrane, which is the result of changes in the fiber structure of PAN 
after multi-step processing. In the filtration process, the application of these materials can be hindered by the poor mechanical strength of the membranes. The poor mechanical strength of the nanofiber membranes is mainly due to their high porosity and the weak bond between random fiber orientation and fiber connections. A unique lamination method can be performed on a supporting layer (e.g., polypropylene/polyethylene biocomponents) to increase the mechanical strength of the nanofibers. The treated membranes showed a significant increase in TS and $Y M$, while maintaining their high porosity and water permeability. Due to their high permeability and mechanical strength, nanofibrous membrane is an excellent for wastewater treatment.

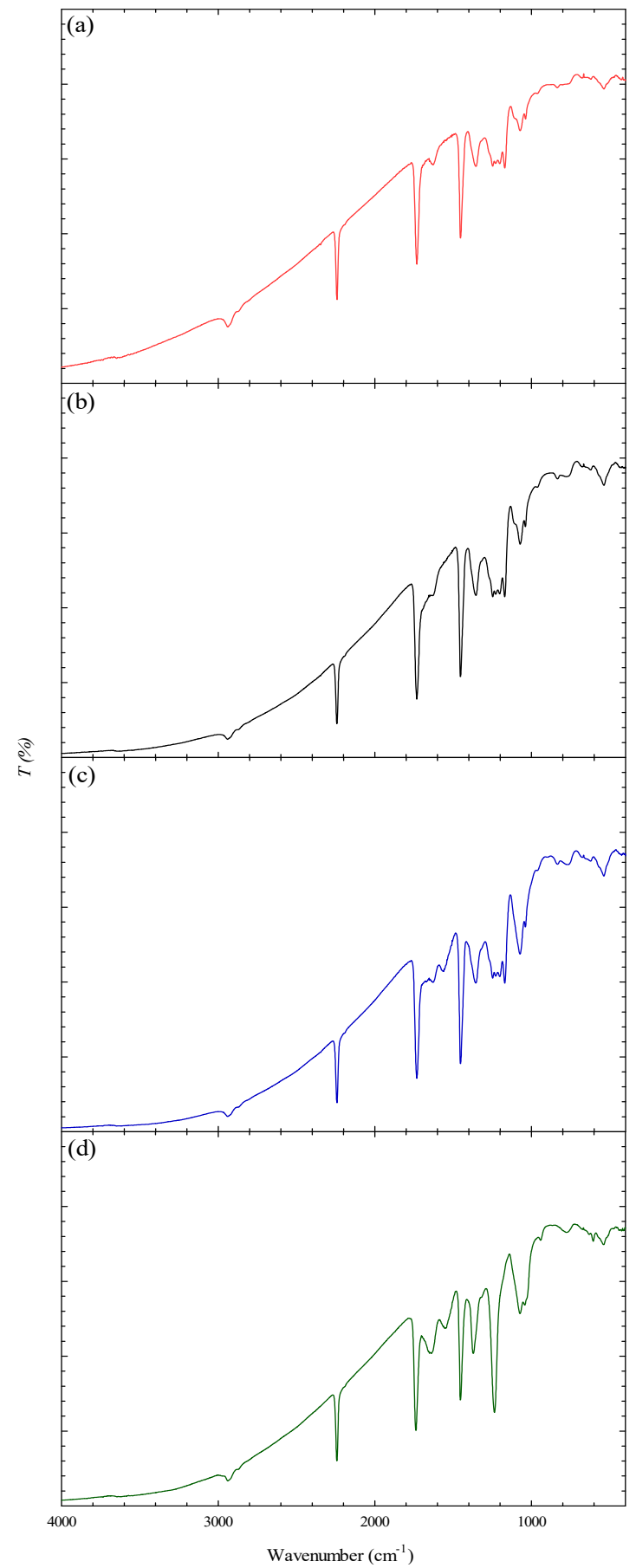

Figure 2. FTIR spectra of (a) PAN, (b) P-COOH, (c) P-COOH-CS, (d) P-COOH-CS-CEW. 

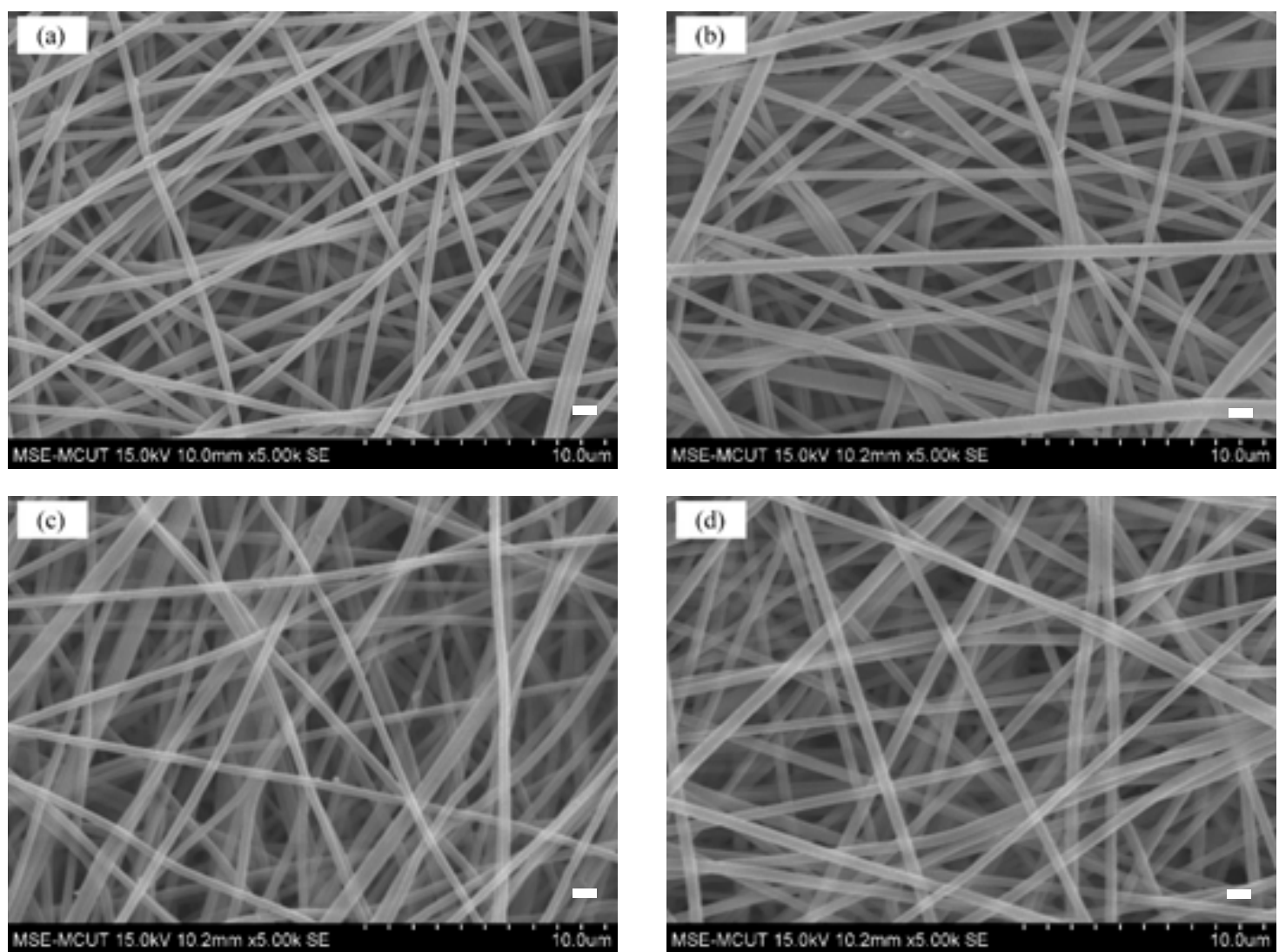

Figure 3. SEM images of (a) PAN, (b) P-COOH, (c) P-COOH-CS, and (d) P-COOH-CS-CEW.

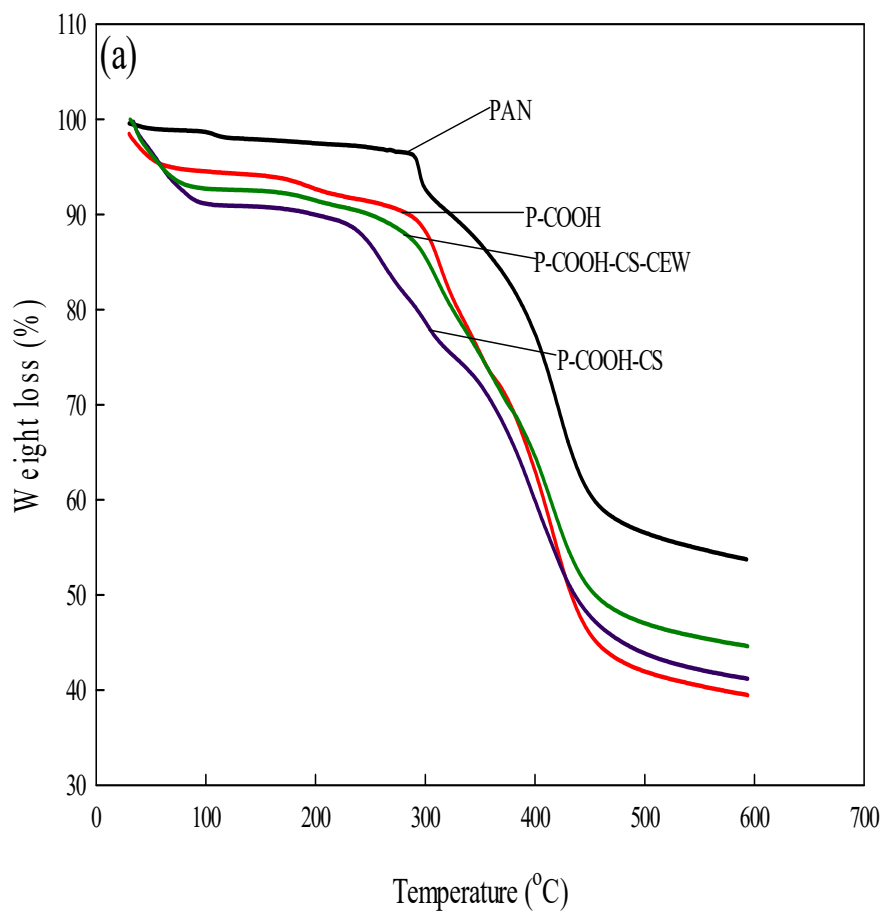

Figure 4. Cont. 


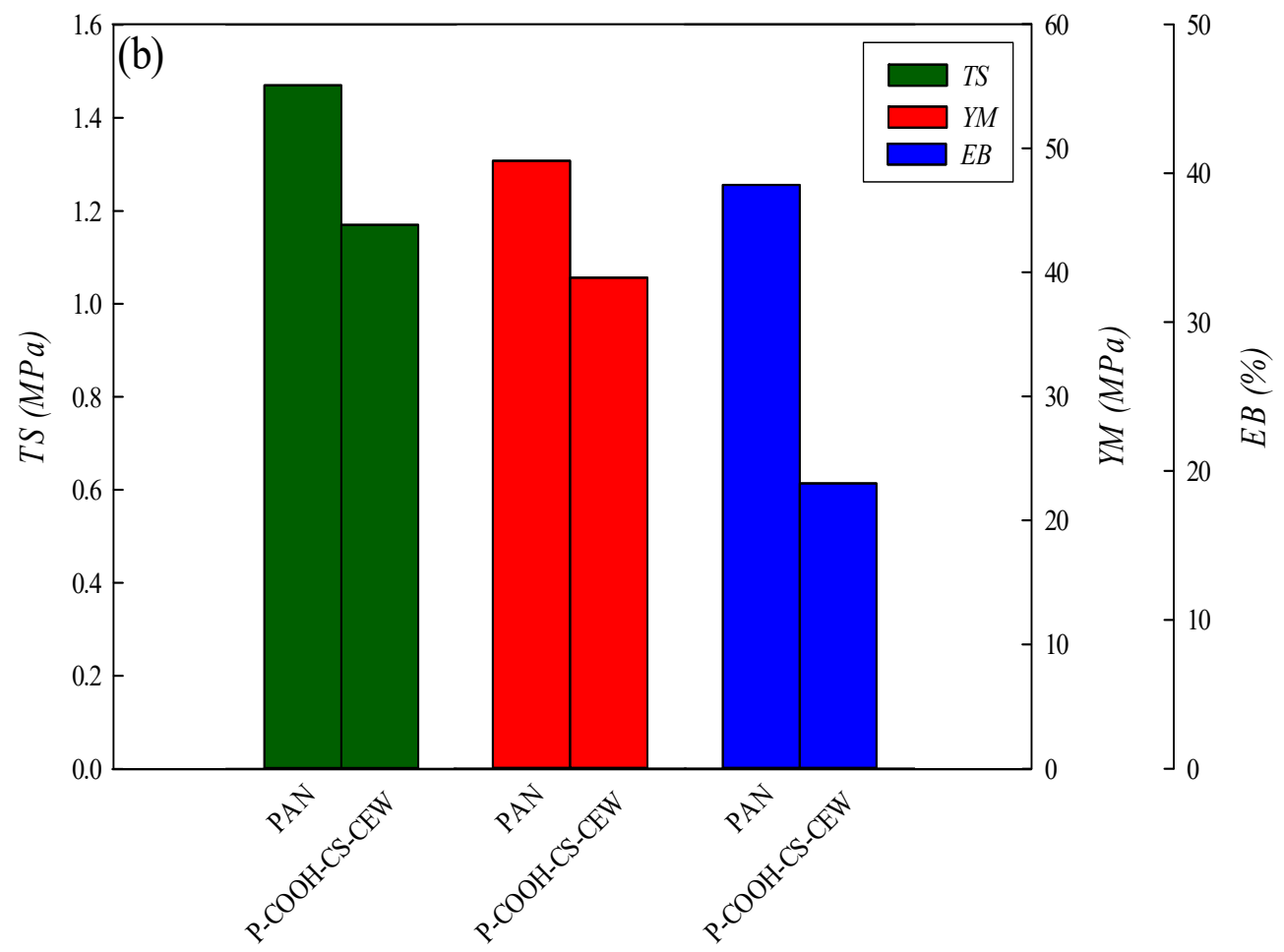

Figure 4. (a) TGA curves of PAN, P-COOH, P-COOH-CS, and P-COOH-CS-CEW. (b) Mechanical properties of PAN and P-COOH-CS-CEW samples: TS, YM, and EB.

\subsection{Effect of Coupling $\mathrm{pH}$ and Loaded Concentration of CEW on Dye Adsorption}

The $\mathrm{pH}$ used in the coupling of $\mathrm{CEW}$ to the $\mathrm{P}-\mathrm{COOH}-\mathrm{CS}$ nanofiber membrane may affect the amount of CEW proteins immobilized on the membrane. In this work, the coupling reaction $\mathrm{pH}$ was investigated between 4 and 7 , and the results of immobilized density of CEW on the membranes are shown in Figure 5a. The immobilization density of CEW increased from $173.21 \mathrm{mg} / \mathrm{g}$ to $176.91 \mathrm{mg} / \mathrm{g}$ when the coupling $\mathrm{pH}$ was adjusted from 4 to 5 . However, the immobilization density decreased to $73.92 \mathrm{mg} / \mathrm{g}$. As a result, a coupling $\mathrm{pH}$ of 5 was selected for the subsequent studies involving the immobilization of CEW proteins.

The effect of loaded concentration of CEW $(0.25-2.0 \mathrm{mg} / \mathrm{mL}, 5 \mathrm{~mL})$ on the immobilized density of CEW on the P-COOH-CS-CEW nanofiber membrane was investigated, and the results of immobilized density of CEW on the membranes are given in Figure $5 \mathrm{~b}$. By increasing the amount of CEW in the reaction solution from $0.25 \mathrm{mg} C E W / \mathrm{mL}$ to $2.0 \mathrm{mg} \mathrm{CEW} / \mathrm{mL}$, the binding capacity for $\mathrm{AO} 7$ and $\mathrm{TBO}$ dyes reached the maximum value of $1.0 \mathrm{mg} C E W / \mathrm{mL}$. However, at the CEW concentration beyond $1.0 \mathrm{mg} / \mathrm{mL}$, the immobilization density decreased to $238.78 \mathrm{mg} / \mathrm{g}$ for $\mathrm{AO} 7$ and $91.56 \mathrm{mg} / \mathrm{g}$ for TBO at a loaded concentration of $0.25 \mathrm{mg} C E W / \mathrm{mL}$. The binding capacity of the P-COOH-CSCEW nanofiber membrane for $\mathrm{AO} 7$ and TBO dyes was decreased by the loaded CEW concentration greater than $1.0 \mathrm{mg} / \mathrm{mL}$. The reduction in binding capacity may be due to the effect of steric hindrance. Hence, the loaded concentration of CEW in the synthesis of $\mathrm{P}-\mathrm{COOH}-\mathrm{CS}-\mathrm{CEW}$ nanofiber membrane was fixed at $1.0 \mathrm{mg} / \mathrm{mL}$. 

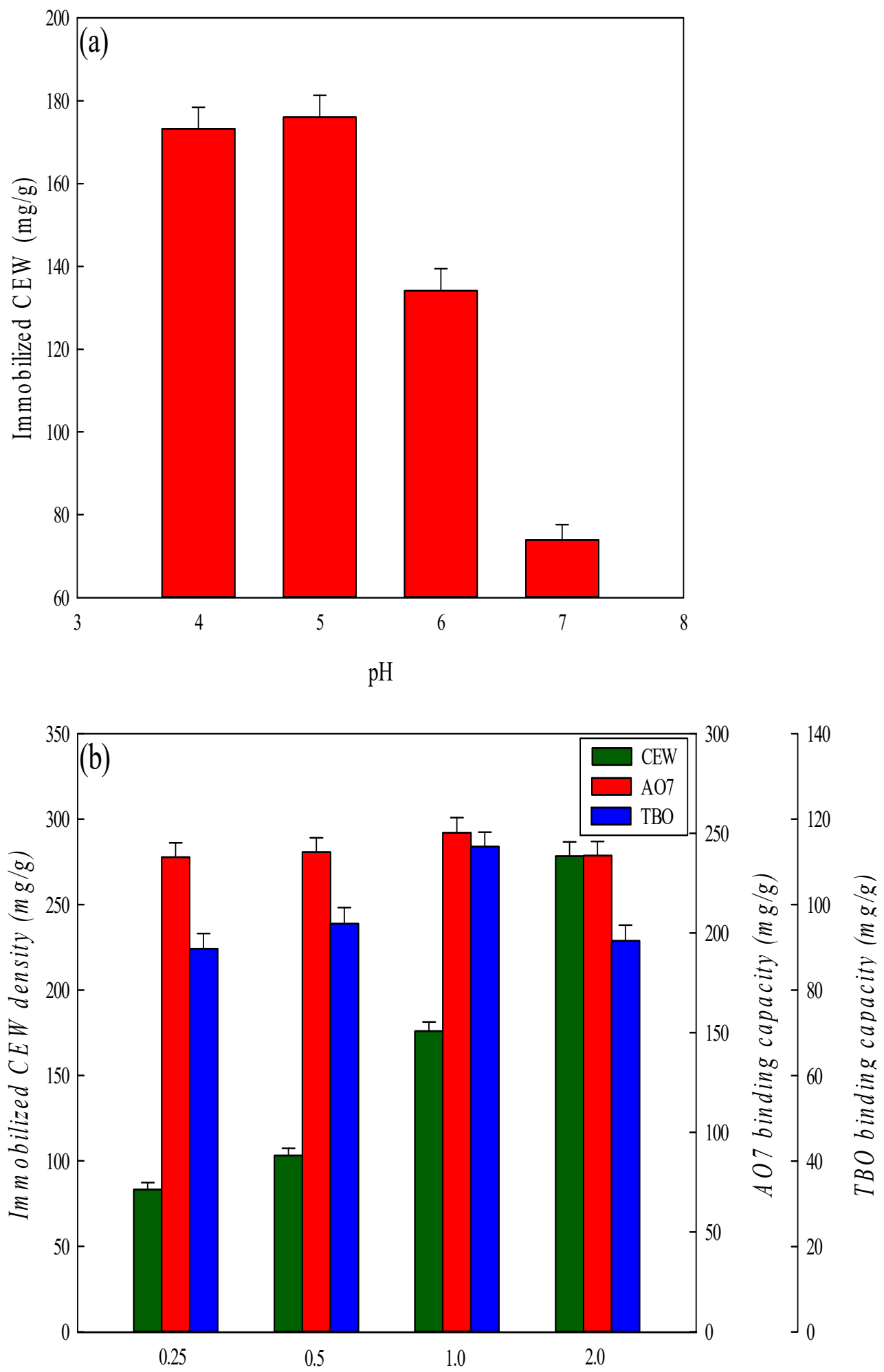

Initial concentration of CEW (mg/mL)

Figure 5. (a) Effect of coupling $\mathrm{pH}$ on the amount of CEW $(1.0 \mathrm{mg} / \mathrm{mL})$ immobilized onto the P-COOH-CS nanofiber membrane. (b) Effect of loaded CEW concentration on the CEW immobilization density on $\mathrm{P}-\mathrm{COOH}-\mathrm{CS}-\mathrm{CEW}$ nanofiber membrane and the TBO binding capacity. Operating conditions: P-COOH-CS-CEW nanofiber membrane ( 0.03 g), CEW concentration $(0.25-2.0 \mathrm{mg} / \mathrm{mL}$, $5 \mathrm{~mL}, \mathrm{pH}$ 5, 3 h, 100 rpm). 


\subsection{Effect of $\mathrm{pH}$ on Dye Adsorption}

In an acidic environment (e.g., $\mathrm{pH}$ 2), the electrostatic interaction between the anionic (i.e., sulfonate) group of $\mathrm{AO} 7$ and the cationic group on the nanofiber membranes could be governed by the residual ammonium groups $\left(-\mathrm{NH}_{3}{ }^{+}\right)$either on the chitosan or on the CEW proteins. Conversely, in an alkaline environment (e.g., pH 10), the interaction between cationic (i.e., ammonium) group on TBO dye and anionic group (carboxyl) on the nanofiber membranes could be facilitated by the residual acidic group $\left(-\mathrm{COO}^{-}\right)$either on the $\mathrm{P}-\mathrm{COOH}$ or on the CEW proteins. The results are shown in Figure 6a. Previous studies have shown that the negatively charged $\mathrm{AO} 7$ dye has a higher binding affinity toward the positively charged membrane in an acidic solution ( $\mathrm{pH}$ 2), while the positively charged TBO dye shows a higher binding affinity toward the negatively charged membranes in an alkaline solution ( $\mathrm{pH} 10)[2,37,40,45]$. Hence, in this work, the optimal $\mathrm{pH}$ for the adsorption of $\mathrm{AO} 7$ and TBO dyes are $\mathrm{pH} 2$ and $\mathrm{pH}$ 10, respectively.

Different nanofiber membranes (i.e., PAN, P-COOH, P-COOH-CS, and P-COOH-CS$\mathrm{CEW})$ were investigated to determine their binding efficiency of $\mathrm{AO} 7 \mathrm{(pH} 2)$ and TBO ( $\mathrm{pH} 10)$ dyes $\left(1 \mathrm{mg} / \mathrm{mL}, 5 \mathrm{~mL}, 25^{\circ} \mathrm{C}\right)$. The binding efficiencies of nanofiber membranes are shown in Figure $6 \mathrm{~b}$. The decreasing order of the binding efficiency is given as: $\mathrm{P}$ COOH-CS-CEW (AO7 $250.35 \mathrm{mg} / \mathrm{g}$, TBO $113.56 \mathrm{mg} / \mathrm{g}$ ) > P-COOH-CS (AO7 $240.28 \mathrm{mg} / \mathrm{g}$, TBO $103.19 \mathrm{mg} / \mathrm{g}$ ) > P-COOH (AO7 $106.67 \mathrm{mg} / \mathrm{g}$, TBO $98.50 \mathrm{mg} / \mathrm{g})>$ PAN $(71.31 \mathrm{mg} / \mathrm{g}$, $40.71 \mathrm{mg} / \mathrm{g}$ ). The ability of these nanofiber membranes to bind the dyes may be dependent on the hydrophobic, hydrophilic, and ionic interactions between dye and membrane. Moreover, the charge properties of the membrane are affected by the adsorption $\mathrm{pH}$. At $\mathrm{pH} \mathrm{2,} \mathrm{the} \mathrm{membrane} \mathrm{carries} \mathrm{mostly} \mathrm{positive} \mathrm{charges,} \mathrm{whereas} \mathrm{at} \mathrm{pH} 10$, it carries mainly negative charges. Since AO7 and TBO dyes contain positive and negative charges, respectively, the functionalized nanofiber membranes containing macromolecules (e.g., $\mathrm{P}-\mathrm{COOH}-\mathrm{CS}$ and $\mathrm{P}-\mathrm{COOH}-\mathrm{CS}-\mathrm{CEW}$ ) have a larger binding capacity for $\mathrm{AO}$ and TBO dyes. Therefore, the macromolecules (e.g., chitosan and protein molecules) coupled to the nanofiber membranes can enhance their binding capacity for the dyes.

The photos of nanofiber membrane are shown in Figure 7. After treatment with AO7 and TBO, P-COOH-CS-CEW nanofiber membranes were stained in dense orange and purple, respectively.

\subsection{Equilibrium Isotherm Studies}

Protein molecules immobilized on the P-COOH-CS-CEW have multifunctional groups with different levels of charge density or hydrophobicity. Therefore, dye molecules could be bound to these multifunctional groups via various interactions (e.g., hydrophobic and/or electrostatic interactions). Under alkaline adsorption conditions ( $\mathrm{pH} 10$ for TBO dye), egg white proteins may be negatively charged [39]. Therefore, the bonding could be formed between the positively charged group of TBO dye and negatively charged - $\mathrm{COOH}$ group of P-COOH-CS-CEW. At $\mathrm{pH}$ 2, the adsorption could be potentially due to the bonding between negatively charged group of the $\mathrm{AO} 7$ dye and the positively charged ammonium group $\left(-\mathrm{NH}_{3}{ }^{+}\right)$of $\mathrm{P}-\mathrm{COOH}-\mathrm{CS}-\mathrm{CEW}$. Hence, it is suggested that the electrostatic interactions between these functional groups are the main forces for the adsorption of $\mathrm{AO} 7$ and $\mathrm{TBO}$ dyes by P-COOH-CS-CEW. 

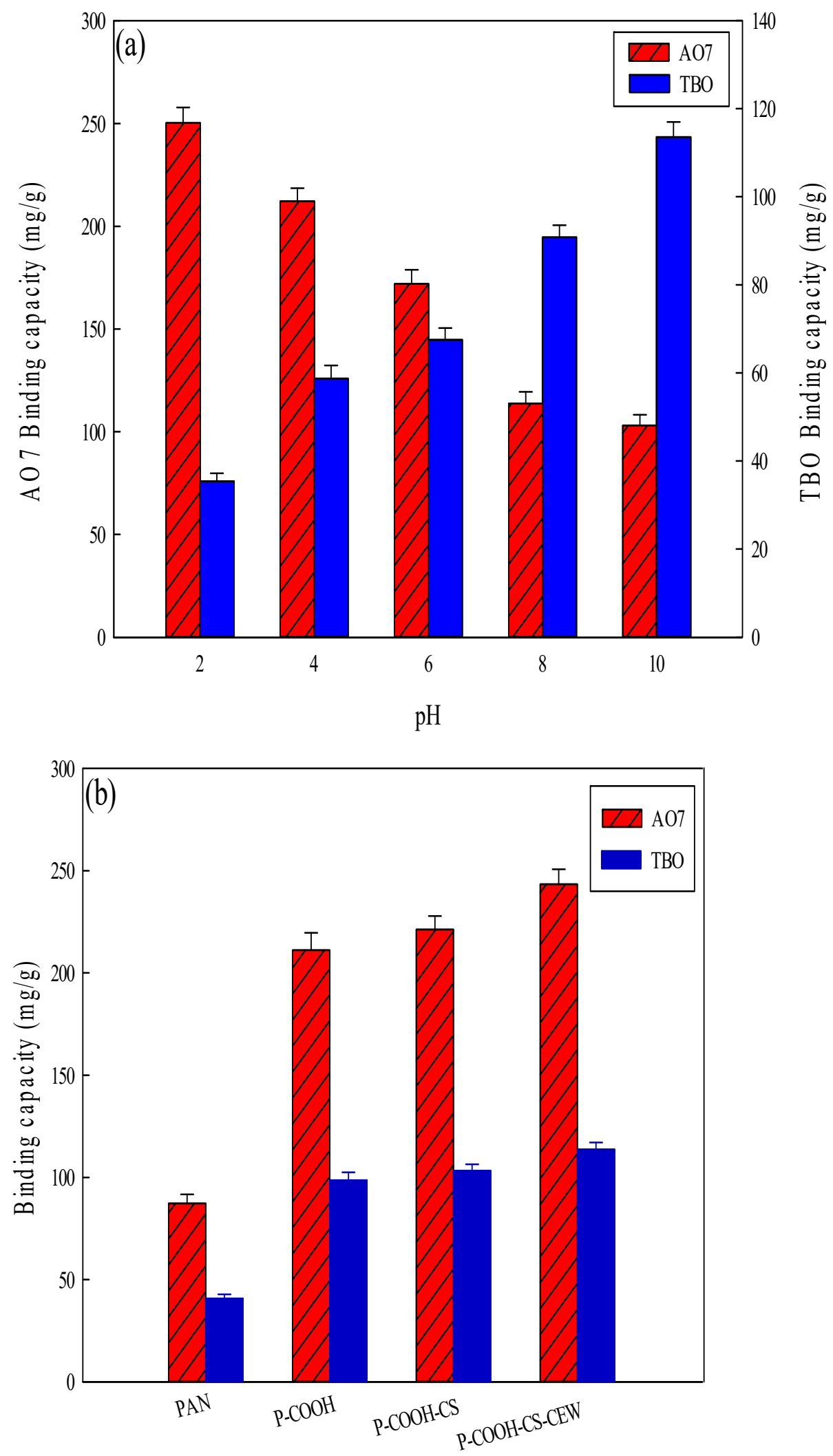

Figure 6. (a) Effect of buffer $\mathrm{pH}$ on the adsorption of AO7 and TBO on P-COOH-CS-CEW nanofiber membrane. (b) A comparison of binding capacity of different nanofiber membranes for AO7 and TBO dyes. Operating conditions: $\sim 0.03 \mathrm{~g}$ of nanofiber membranes incubated in $5 \mathrm{~mL}$ of dye solution $[1 \mathrm{mg} / \mathrm{mL}$ of $\mathrm{AO} 7(\mathrm{pH} 2)$ or $\mathrm{TBO}(\mathrm{pH} 10)]$ at $150 \mathrm{rpm}$ and $25^{\circ} \mathrm{C}$ for $3 \mathrm{~h}$. 
(a)

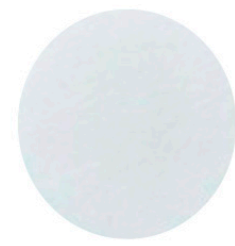

(d)

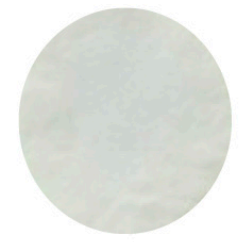

(b)

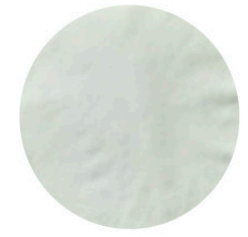

(e)

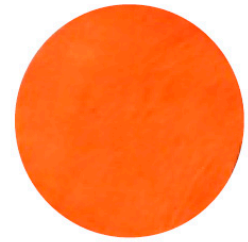

(c)

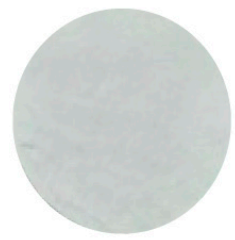

(f)

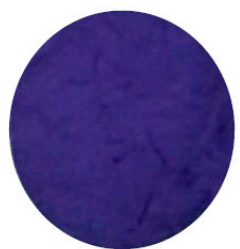

Figure 7. Photos of nanofiber membranes: (a) PAN, (b) P-COOH, (c) P-COOH-CS, (d) P-COOH-CSCEW, (e) P-COOH-CS-CEW treated with AO7, and (f) P-COOH-CS-CEW treated with TBO.

Isothermal adsorption behavior of P-COOH-CS-CEW for AO7 and TBO dyes (initial dye concentration: $0.1-5.0 \mathrm{mg} / \mathrm{mL}$ ) was investigated, and the results are shown in Figure $8 \mathrm{a}, \mathrm{b}$ and Table 1 . The experiment data were fitted to three equilibrium isotherm models (Langmuir, Freundlich, and Langmuir-Freundlich models) using Equations (1)-(3), respectively [46]:

$$
\begin{gathered}
\frac{C^{*}}{q^{*}}=\frac{K_{L}}{q_{\max }}+\frac{C^{*}}{q_{\max }} \\
\ln q^{*}=\ln K_{F}+\frac{1}{n} \ln C^{*} \\
\ln \frac{q^{*}}{q_{\max }-q^{*}}=n \ln C^{*}-\ln K_{L F}
\end{gathered}
$$

where $C^{*}\left(\mathrm{mg} / \mathrm{mL}\right.$ solution) is equilibrium dye concentration in the aqueous phase, $q^{*}$ (mg/g membrane) is the amount of dye on the membrane solid phase, and $q_{\max }$ is the maximum capacity binding of P-COOH-CS-CEW $(\mathrm{mg} / \mathrm{g}) . K_{L}$ is the dissociation equilibrium constant (mg dye/mL) of the membrane-dye complex fitted by Langmuir model, and the reciprocal $K_{L}$ value is the equilibrium constant. $K_{F}$ and $1 / n$ values are the adsorption constants in Freundlich model. $K_{L F}$ represents the dissociation constant $(\mathrm{mg} / \mathrm{mL})$ of the complex in Langmuir-Freundlich model, and $1 / n$ is the Freundlich coefficient, which represents the characteristic parameter, where $1 / n=1$, the adsorption conforms to the Langmuir equation. $1 / n>1$ means that the adsorption phenomenon is a positive synergy; $0<1 / n<1$ is a negative synergy.

The curve fitted by Langmuir model was rearranged into linear form as shown in Figure 8c,d; the fitting of experiment results for both AO7 and TBO dyes yields the high linear coefficient of determination $\left(R^{2}=0.998\right)$. However, the experiment results did not fit well to the adsorption behavior described by Freundlich $\left(R^{2}=0.968-0.986\right)$ and LangmuirFreundlich adsorption models $\left(R^{2}=0.813-0.961\right)$, as shown in Figure 8e-h, respectively. Based on Langmuir model, the maximum equilibrium adsorption capacity and dissociation constant of AO7 adsorption process by nanofiber membrane were $329.36 \mathrm{mg} / \mathrm{g}$ and $0.038 \mathrm{mg} / \mathrm{mL}$, respectively; the equilibrium binding constant was $K_{e q}=26.32 \mathrm{~mL} / \mathrm{mg}$. For the adsorption of TBO dye, the maximum equilibrium binding capacity and dissociation constant were $317.16 \mathrm{mg} / \mathrm{g}$ and $0.107 \mathrm{mg} / \mathrm{mL}$, respectively; the equilibrium binding constant $\left(K_{e q}\right)$ is $9.35 \mathrm{~mL} / \mathrm{mg}$. The results suggested that binding capacities of P-COOH-CSCEW nanofiber membranes for both dyes are the same. Nevertheless, for the case of AO7 dye adsorption by $\mathrm{P}-\mathrm{COOH}-\mathrm{CS}-\mathrm{CEW}$ nanofiber membranes, a greater value of equilibrium binding constant implies that the protein-modified membrane has a higher binding affinity for AO7. Therefore, the binding strength between AO7 and P-COOH-CS-CEW would be higher. The possible reason is that the electrostatic interaction is the main force involved in 
the dye adsorption process. In addition, the combination of hydrophobic interaction and hydrogen bond may be present between the dye and P-COOH-CS-CEW nanofiber membrane. Thus, the intermolecular interactions, including electrostatic attraction, Van der Waals interaction, and hydrogen bonding, are expected to take place between P-COOH-CS-CEW nanofiber membrane and the dye.
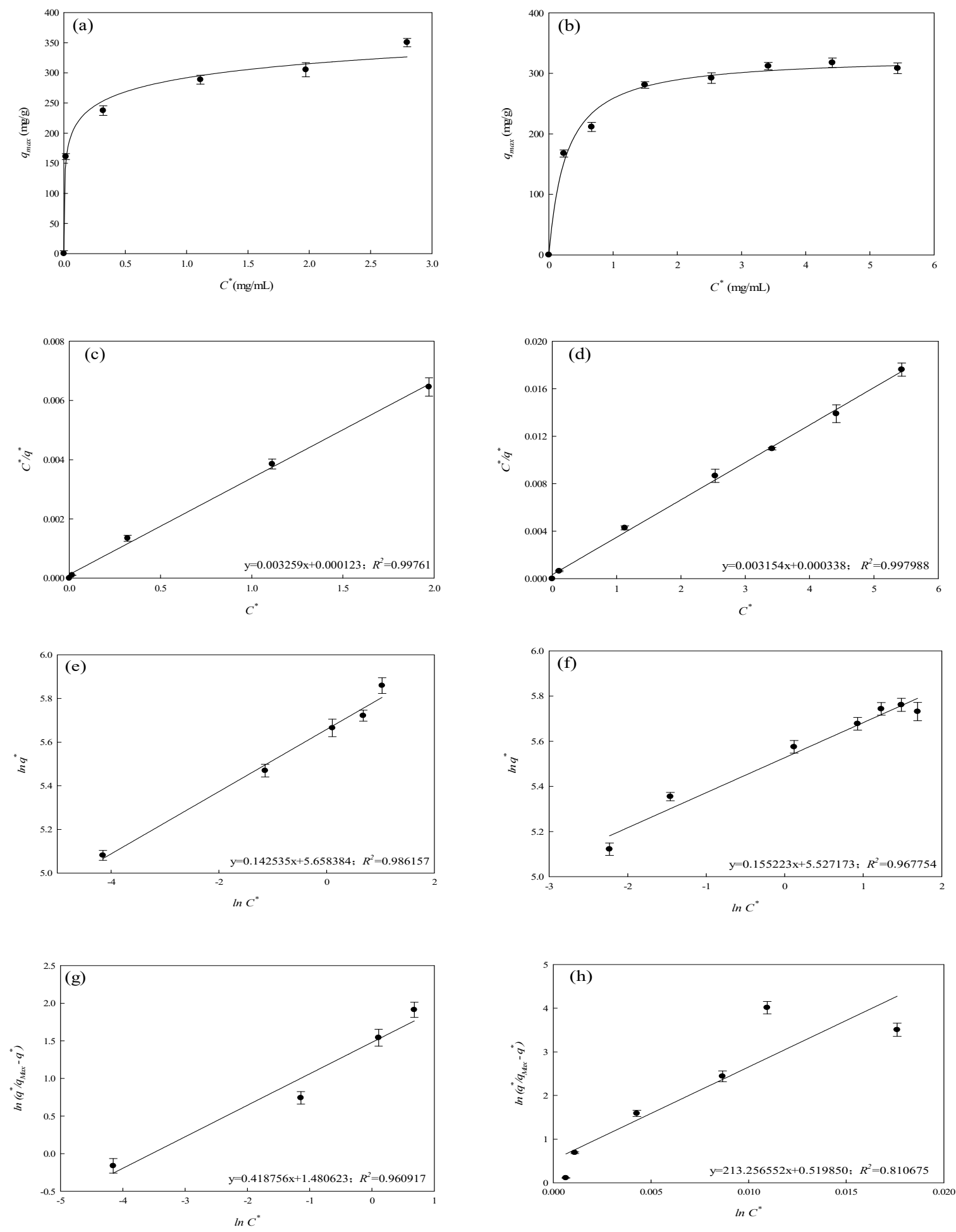

Figure 8. Equilibrium adsorption isotherms for $(\mathbf{a}, \mathbf{c}, \mathbf{e}, \mathbf{g}) \mathrm{AO}$ and $(\mathbf{b}, \mathbf{d}, \mathbf{f}, \mathbf{h})$ TBO on P-COOH-CS-CEW nanofiber membrane. Equilibrium adsorption isotherms fitted by Langmuir model (c,d), Freundlich model (e,f), and Langmuir-Freundlich model (g,h). 
Table 1. Equilibrium and thermodynamic parameters calculated using equilibrium isotherm models for determining the adsorption behavior of P-COOH-CS-CEW nanofiber membrane for AO7 and $\mathrm{TBO}$.

\begin{tabular}{ccccccccc}
\hline & Langmuir & & & Freundlich & & \multicolumn{3}{c}{ Langmuir-Freundlich } \\
\hline $\begin{array}{c}\boldsymbol{q}_{\text {max }, \text { cal }} \\
(\mathbf{m g} / \mathbf{m L})\end{array}$ & $\begin{array}{c}\boldsymbol{K}_{\mathbf{L}} \\
(\mathbf{m g} / \mathbf{m L})\end{array}$ & $\boldsymbol{R}^{\mathbf{2}}$ & $\boldsymbol{n}_{\boldsymbol{F}}$ & $\begin{array}{c}\boldsymbol{K}_{\boldsymbol{F}} \\
(\mathbf{m g} / \mathbf{m L})\end{array}$ & $\boldsymbol{R}^{\mathbf{2}}$ & $\boldsymbol{n}_{L F}$ & $\begin{array}{c}\boldsymbol{K}_{L F} \\
(\mathbf{m g} / \mathbf{m L})\end{array}$ \\
\hline 329.36 & 0.038 & 0.998 & 7.016 & 286.7 & 0.986 & 0.419 & 4.396 & 0.961 \\
317.16 & 0.107 & 0.998 & 6.442 & 251.4 & 0.968 & 213.3 & 1.682 & 0.811 \\
\hline
\end{tabular}

\subsection{Kinetic Adsorption Studies}

Figure 9a-f and Table 2 show the results of the kinetics of dye adsorption by $\mathrm{P}-\mathrm{COOH}-$ CS-CEW nanofiber membrane at various concentrations of dyes $(1-3 \mathrm{mg} / \mathrm{mL})$. It was found that the adsorption of AO7 and TBO ceased after about 30 min (Figure 9a) and $90 \mathrm{~min}$ (Figure 9b), respectively. Therefore, P-COOH-CS-CEW nanofiber membrane has a higher selectivity for $\mathrm{AO} 7$ dye than $\mathrm{TBO}$ dye. When the initial dye concentration increased from 1.0 to $3.0 \mathrm{mg} / \mathrm{mL}$, the concentration of adsorbed $\mathrm{AO}$ dye increased from 236.57 to $337.75 \mathrm{mg} / \mathrm{g}$; in contrast, the concentration of adsorbed TBO dye increased from 104.49 to $304.33 \mathrm{mg} / \mathrm{g}$. The increase in concentration of adsorbed dyes led to a higher removal rate because of the difference in concentration between liquid and solid (membrane) phase. The drastic concentration difference between adsorbent and liquid phase facilitates the collision between dye molecular and membrane binding site. As CEW proteins are immobilized on the surface of the P-COOH-CS-CEW nanofiber membrane, the adsorption of dye molecules at the outer surface of the membrane was expected.

Two adsorption models, namely, pseudo first- and second-order kinetic models [Equations (4) and (5), respectively] [47], were applied in the study of adsorption kinetics of P-COOH-CS-CEW nanofiber membrane and in the determination of the adsorption rate constant for the cases of $\mathrm{AO} 7$ and $\mathrm{TBO}$ adsorptions.

$$
\begin{gathered}
\ln \left(q_{1}-q_{t}\right)=\ln q_{1}-k_{1} t \\
\left(\frac{t}{q_{t}}\right)=\left(\frac{1}{k_{2} q_{2}^{2}}\right)-\left(\frac{1}{q_{2}}\right) t
\end{gathered}
$$

where $q_{1}, q_{2}$, and $q_{t}$ represent the binding capacity $(\mathrm{mg} / \mathrm{g})$ of nanofiber membrane for dye at any given time $t$ and at equilibrium, $t$ is the adsorption time, $k_{1}$ is the pseudo first-order kinetics rate constant, $k_{2}$ is pseudo second-order kinetics rate constant. Table 2 shows the adsorption rate constants derived from the fitting of pseudo first- and second-order kinetic adsorption model, as well as the binding capacity of P-COOH-CS-CEW for AO7 and TBO dyes. The pseudo first-order kinetic adsorption model gave the low $R^{2}$ values $(<0.0480$ for AO7 dye, Figure 9c; $<0.0874$ for TBO dye, Figure 9d), and therefore it is not suitable for describing the adsorption behavior. Figure $9 \mathrm{e}, \mathrm{f}$ show the performance of the data fitting by pseudo second-order kinetic model, which gave the high $R^{2}$ values (>0.997); pseudo second-order kinetic models are hence suitable for describing the dye adsorption behavior. Moreover, the surface reaction on the nanofiber membrane may be the rate-determining step of dye adsorption. In the case of the pseudo second-order kinetics, the calculated $q_{c a l}$ value for AO7 dye adsorption is $345.12 \mathrm{mg} / \mathrm{g}$, which is quite close to the maximum adsorbed amount of AO7 $(333.75 \mathrm{mg} / \mathrm{g})$ as described by Langmuir model. For the adsorption of TBO by P-COOH-CS-CEW nanofiber membrane, the calculated binding capacity $\left(q_{c a l}=318.01 \mathrm{mg} / \mathrm{g}\right)$ is close to the maximum adsorbed amount of TBO $(317.16 \mathrm{mg} / \mathrm{g}$ ) as described by the Langmuir model. 

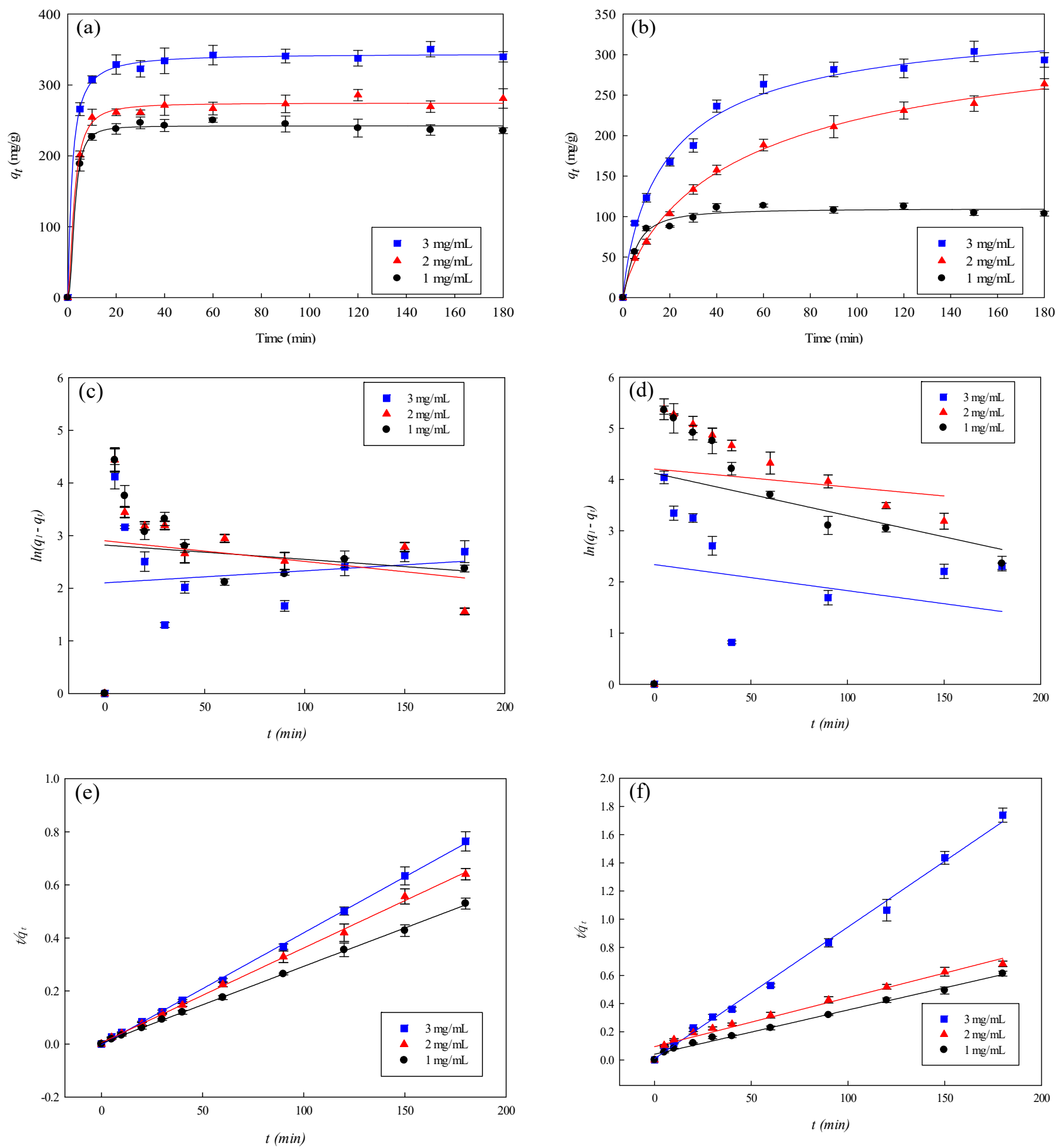

Figure 9. Adsorption rates of P-COOH-CS-CEW nanofiber membrane for (a) AO7 and (b) TBO dyes. Kinetic adsorption of (c) AO7 and (d) TBO fitted by pseudo first-order model. Kinetic adsorption of (e) AO7 and (f) TBO fitted by pseudo second-order model. 
Table 2. Pseudo first-order and pseudo second-order kinetic rate constants, calculated and experiment $q$ values for the adsorption of $\mathrm{AO} 7$ and TBO dyes onto the P-COOH-CS-CEW nanofiber membrane at different dye concentrations.

\begin{tabular}{|c|c|c|c|c|c|c|}
\hline \multicolumn{2}{|c|}{ Kinetic Model } & \multicolumn{3}{|c|}{ Pseudo Second-Order Model } & \multicolumn{2}{|c|}{ Pseudo First-Order Model } \\
\hline $\begin{array}{c}\mathrm{AO} 7 \\
(\mathrm{mg} / \mathrm{mL})\end{array}$ & $\begin{array}{c}q_{\exp } \\
(\mathrm{mg} / \mathrm{g})\end{array}$ & $\begin{array}{c}q_{2, c a l} \\
(\mathrm{mg} / \mathrm{g})\end{array}$ & $\begin{array}{c}k_{2} \\
(\mathrm{~g} / \mathrm{mg} \cdot \min )\end{array}$ & $R^{2}$ & $\begin{array}{c}k_{1} \\
(1 / \min )\end{array}$ & $R^{2}$ \\
\hline 1 & 250.35 & 237.03 & $7.37 \times 10^{-3}$ & 0.9994 & $2.03 \times 10^{-3}$ & 0.0181 \\
\hline 2 & 285.76 & 280.01 & $2.50 \times 10^{-3}$ & 0.9989 & $3.94 \times 10^{-3}$ & 0.0430 \\
\hline 3 & 337.75 & 345.12 & $2.70 \times 10^{-3}$ & 0.9995 & $2.74 \times 10^{-3}$ & 0.0183 \\
\hline $\begin{array}{c}\text { TBO } \\
(\mathrm{mg} / \mathrm{mL})\end{array}$ & $\begin{array}{c}q_{\exp } \\
(\mathrm{mg} / \mathrm{g})\end{array}$ & $\begin{array}{c}q_{2, \mathrm{cal}} \\
(\mathrm{mg} / \mathrm{g})\end{array}$ & $\begin{array}{c}k_{2} \\
(\mathrm{~g} / \mathrm{mg} \cdot \mathrm{min})\end{array}$ & $R^{2}$ & $\begin{array}{c}k_{1} \\
(1 / \mathrm{min})\end{array}$ & $R^{2}$ \\
\hline 1 & 113.56 & 106.98 & $9.06 \times 10^{-3}$ & 0.9963 & $5.10 \times 10^{-3}$ & 0.0536 \\
\hline 2 & 263.85 & 286.88 & $1.29 \times 10^{-4}$ & 0.9725 & $3.51 \times 10^{-3}$ & 0.0129 \\
\hline 3 & 304.33 & 318.01 & $2.45 \times 10^{-4}$ & 0.9921 & $8.28 \times 10^{-3}$ & 0.0874 \\
\hline
\end{tabular}

\subsection{Desorption Studies}

Studies of adsorption-desorption characteristics are crucial for assessing the regeneration and reusability of the membrane adsorbent. To study the possibility of regenerating P-COOH-CS-CEW nanofiber membrane for multiple rounds of adsorption-desorption, various salts [1 $\mathrm{M}, \mathrm{NaCl},\left(\mathrm{NH}_{4}\right)_{2} \mathrm{SO}_{4}$, and $\left.\mathrm{KSCN}\right]$ dissolved in different organic solvents (50\% ethanol, ethylene glycol, and glycerol) were used for desorption. As shown in Figure $10 \mathrm{a}, \mathrm{b}$, depending on the combinations of organic solvents and salts as dye-elution reagent, the complete elution of $\mathrm{AO} 7$ and $\mathrm{TBO}$ dyes from $\mathrm{P}-\mathrm{COOH}-\mathrm{CS}-\mathrm{CEW}$ nanofiber membrane can be attained. This implied that the electrostatic or van der Waals forces were present between dye and binding site on the nanofiber membrane. However, there may be other intermolecular forces between the dye and protein on the P-COOH-CS-CEW nanofiber membrane (e.g., hydrophobic and hydrogen bonding). The adsorbed dyes, either $\mathrm{AO} 7$ or TBO, can be thoroughly eluted from the P-COOH-CS-CEW nanofiber membrane by $1 \mathrm{M} \mathrm{NaCl}$ solution containing 50\% ethanol, as shown in Figure 10c,d. Finally, after five adsorption-desorption cycle tests, the binding capacity of P-COOH-CS-CEW nanofiber membrane for both dyes remained at $\sim 97 \%$, indicating that the P-COOH-CS-CEW nanofiber membrane has good potential for the repeated use in dye wastewater treatment.

\subsection{Remarks on Protein Modified Nanofiber Membrane for Dye Waste Treatment}

Dye wastewater has severe negative effects on the environment if it is not pretreated properly. Adsorption technique can be an effective approach for the treatment of dye wastewater. However, the conventional adsorption techniques may have low efficiency in dye removal. To improve the interaction between the dye and P-COOH-CS-CEW nanofiber membrane, natural polysaccharides (i.e., chitosan) and CEW proteins have been coupled onto $\mathrm{P}-\mathrm{COOH}$ nanofiber membrane with the aim to improve the dye adsorption via the effects of electrostatic attraction, van der Waals force, and hydrogen bonding. These molecular interactions between the hydrophobic group of dye and non-polar side chain of amino acid residue are responsible for the improved adsorption performance. The charge properties of the protein can be adjusted via buffer $\mathrm{pH}$. In this case, the protein molecules immobilized on the P-COOH-CS-CEW nanofiber membrane not only can remove the positively charged dye, but also remove negatively charged dye. The results of this study are compared with other published studies on the adsorption of AO7 [2,48-52] and TBO $[8,10,12,14,15,40,47]$ as shown in Table 3 . The removal efficiency of AO7 by P$\mathrm{COOH}-\mathrm{CS}-\mathrm{CEW}$ nanofiber membrane is higher than that of the conventional adsorbents used in other reported studies. As for the removal of TBO, the performances of nanofiber membranes immobilized with CEW or BSA (i.e., P-COOH-CS-CEW, P-COOH-CEW, P$\mathrm{COOH}-\mathrm{BSA}$ ) are superior to other conventional adsorbents. From this comparison, it is clear that proteins immobilized on the nanofiber membranes could act as a good adsorbent of dye. However, the binding capacity of P-COOH-CS-CEW nanofiber membrane for TBO was 
lower than that of P-COOH-BSA or P-COOH-CEW nanofiber membranes. This decrease might be attributed to steric effects generated by the high concentration of chitosan and CEW molecules on the P-COOH-CS-CEW nanofiber membrane. The TBO dye molecules may be unable to approach the binding sites on the CEW protein molecules. As a result, the degree of steric hindrances between the CEW protein molecules increased, resulting in the decrease in the membrane's binding capacity of the membrane for TBO dye.
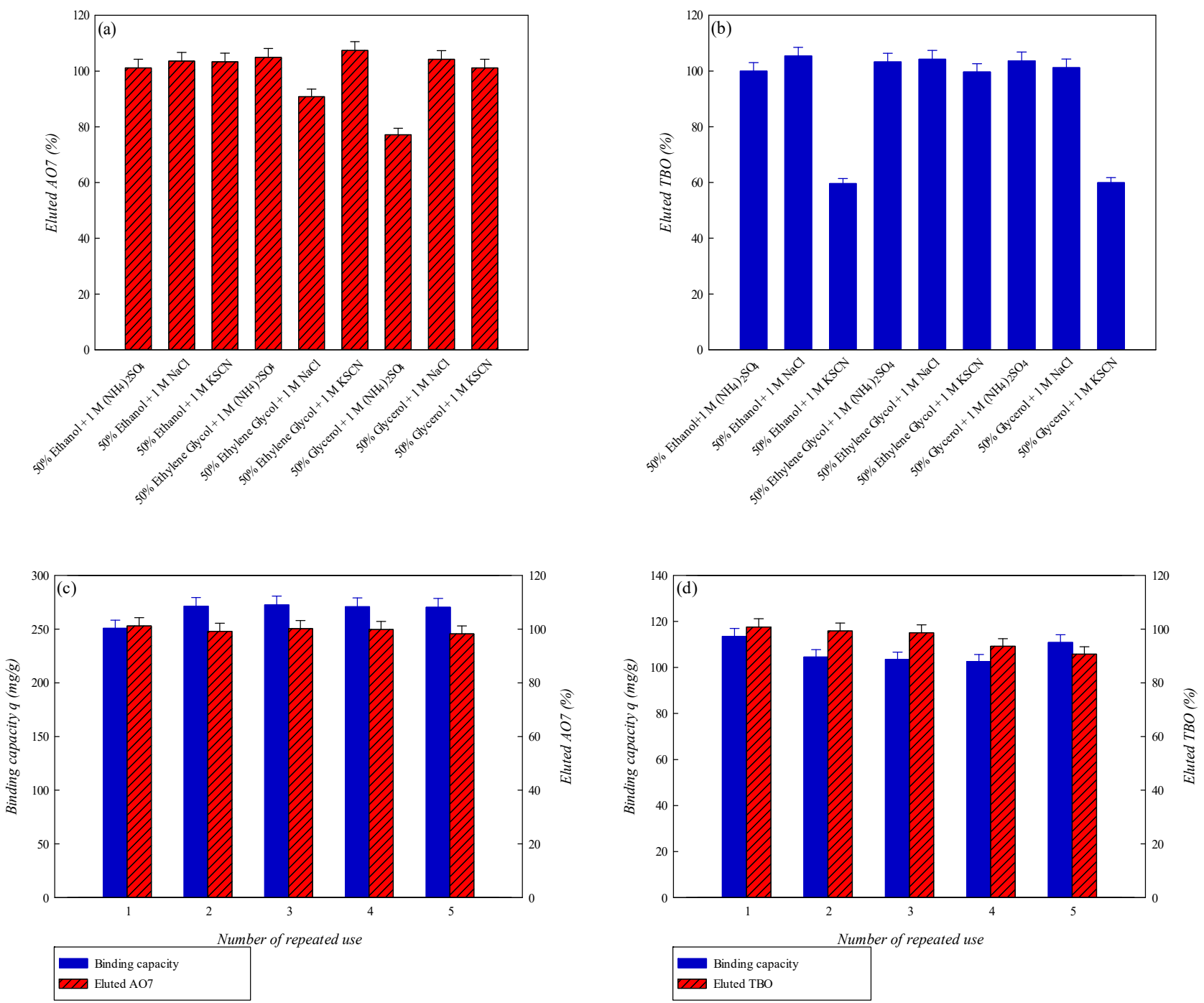

Figure 10. Adsorption-desorption, repeated use, and regenerated binding capacity of P-COOH-CSCEW nanofiber membrane for the removal of AO7 and TBO dyes: (a) Eluted AO7 (\%), (b) Eluted TBO (\%), (c) Binding capacity for AO7 after repeated use, and (d) Binding capacity for TBO after repeated use.

The nanofiber membranes functionalized with protein for the removal of ionic dyes from wastewater are currently established at the laboratory scale. There are several challenges in transitioning this technique from the laboratory scale to the commercial applications; for example, the mass production of this nanofiber membrane is restricted by the availability of large-scale electrospinning devices and the difficulty of chemical modification of the membrane. Furthermore, the limited stability and the low reliability of the commercial electrospinning process in the fabrication of uniform and high-quality nanofibers remain the significant concerns that must be addressed. Furthermore, the nanofibers' limited mechanical stability and reusability hinder their capability to be used 
in the large-scale water and wastewater treatment. Hence, there is a need for developing advanced technological solutions to improve the physical and chemical performances of nanofibers [53-55]. The suggestions for future works are as follows: (1) Further improvement of the stability, mechanical strength, and reusability of nanofiber membranes by means such as adjustment of the compositions of polymer solutions or water-insoluble polymer solutions; (2) Design and application of nanofiber membrane reactor in dynamic adsorption membrane chromatography.

Table 3. Comparison of adsorption capacity of various adsorbers for AO7 and TBO dyes.

\begin{tabular}{cccc}
\hline Type of Adsorbent & $\boldsymbol{q}_{\max }(\mathbf{m g} / \mathbf{g})$ & $\boldsymbol{q}_{\max }(\boldsymbol{\mu} \mathbf{m o l} / \mathbf{g})$ & Reference \\
\hline & AO7 & & \\
\hline P-COOH-CS-CEW Nanofiber membrane & 329 & 939 & This work \\
Magnetic graphene/chitosan & 43 & 122 & {$[2]$} \\
Canola stalk & 25 & 72 & {$[49]$} \\
Spent brewery grains & 30 & 87 & {$[52]$} \\
Untreated sugarcane bagasse & 28 & 80 & {$[56]$} \\
Azolla rongpong & 77 & 220 & {$[51]$} \\
Beech wood sawdust & 5 & 14 & {$[57]$} \\
Bottom ash & 4 & 12 & {$[48]$} \\
\hline & TBO & & This work \\
P-COOH-CS-CEW Nanofiber membrane & 317 & 1037 & {$[42]$} \\
P-COOH-BSA Nanofiber membrane & 435 & 1422 & {$[43]$} \\
P-COOH-CEW Nanofiber membrane & 546 & 1785 & {$[8]$} \\
Mesoporous silica & 57 & 176 & {$[12]$} \\
Magnetic multi-walled carbon nanotube & 53 & 239 & {$[15]$} \\
Almond shell (Prunus dulcis) & 73 & 88 & {$[47]$} \\
Water-insoluble starch sulfate & 27 & 92 & {$[14]$} \\
Gypsum & 28 & 210 & {$[10]$} \\
Turkish zeolite & 64 & 380 & {$[40]$} \\
Polysulphone-COOH Nanofiber membrane & 116 & 121 & {$[58]$} \\
Silica-iron oxide nanoparticles & 37 &
\end{tabular}

\section{Conclusions}

This study demonstrates the excellent capability of protein-immobilized nanofiber membranes for adsorbing dyes from the simulated wastewater. In specific, $\mathrm{P}-\mathrm{COOH}-$ CS-CEW nanofiber membrane can be used to effectively remove both positively charged $\mathrm{TBO}$ and negatively charged $\mathrm{AO} 7$ dyes from aqueous solutions. The binding between dye and P-COOH-CS-CEW nanofiber membrane was mainly driven by the electrostatic forces. The isothermal adsorption studies showed that the equilibrium adsorption behavior can be described by Langmuir model, while the adsorption kinetic studies showed that the dye adsorption behavior conformed to the pseudo second-order kinetic model. The maximum removal rate of AO7 by $\mathrm{P}-\mathrm{COOH}-\mathrm{CS}-\mathrm{CEW}$ nanofiber membrane was achieved within $30 \mathrm{~min}$, recording the maximum amount of dye absorbed $(329.36 \mathrm{mg} / \mathrm{g})$. In contrast, the adsorption of TBO by P-COOH-CS-CEW nanofiber membrane took around $90 \mathrm{~min}$ to reach an equilibrium, and the amount of TBO adsorbed was as high as $317.16 \mathrm{mg} / \mathrm{g}$. In addition, the repeated uses of P-COOH-CS-CEW nanofiber membrane did not significantly reduce the subsequent binding efficiency of nanofiber membrane for the dyes. Therefore, P-COOH-CS-CEW nanofiber membrane is regarded as a potential high-efficiency adsorbent that can remove cationic and anionic dyes from the contaminated water source. 


\begin{abstract}
Author Contributions: Conceptualization, Y.-K.C.; methodology, Y.-S.C.; validation, Y.-K.C. and S.S.-S.W.; formal analysis, Y.-S.C.; investigation, Y.-S.C.; resources, C.-Y.C.; writing-original draft preparation, Y.-K.C., C.W.O. and S.S.-S.W.; writing-review and editing, Y.-K.C., C.W.O., P.L.S. and S.S.-S.W.; visualization, Y.-S.C., B.C.H. and W.S.C.; supervision, Y.-K.C. and S.S.-S.W.; project administration, Y.-K.C. and S.S.-S.W.; funding acquisition, Y.-K.C. All authors have read and agreed to the published version of the manuscript.
\end{abstract}

Funding: This research was funded by the Ministry of Science and Technology, Taiwan (grant number: MOST 107-2221-E-131-013).

Data Availability Statement: Due to the nature of this research, participants in this study did not agree for their data to be shared publicly, so supporting data are not available.

Conflicts of Interest: The authors declare no conflict of interest.

\title{
References
}

1. Katheresan, V.; Kansedo, J.; Lau, S.Y. Efficiency of various recent wastewater dye removal methods: A review. J. Environ. Chem. Eng. 2018, 6, 4676-4697. [CrossRef]

2. Sheshmani, S.; Ashori, A.; Hasanzadeh, S. Removal of Acid Orange 7 from aqueous solution using magnetic graphene/chitosan: A promising nano-adsorbent. Int. J. Biol. Macromol. 2014, 68, 218-224. [CrossRef]

3. Ali, H. Biodegradation of Synthetic Dyes-A Review. Water Air Soil Pollut. 2010, 213, 251-273. [CrossRef]

4. Donia, A.M.; Atia, A.A.; Al-amrani, W.A.; El-Nahas, A.M. Effect of structural properties of acid dyes on their adsorption behaviour from aqueous solutions by amine modified silica. J. Hazard. Mater. 2009, 161, 1544-1550. [CrossRef] [PubMed]

5. Dutta, S.; Basu, J.K.; Ghar, R.N. Studies on adsorption of p-nitrophenol on charred saw-dust. Sep. Purif. Technol. 2001, 21, 227-235. [CrossRef]

6. Guibal, E.; Roussy, J. Coagulation and flocculation of dye-containing solutions using a biopolymer (Chitosan). React. Funct. Polym. 2007, 67, 33-42. [CrossRef]

7. Kornaros, M.; Lyberatos, G. Biological treatment of wastewaters from a dye manufacturing company using a trickling filter. J. Hazard. Mater. 2006, 136, 95-102. [CrossRef] [PubMed]

8. Melendez-Ortiz, H.I.; Puente-Urbina, B.; Mercado-Silva, J.A.; Garcia-Uriostegui, L. Adsorption performance of mesoporous silicas towards a cationic dye. Influence of mesostructure on adsorption capacity. Int. J. Appl. Ceram. Technol. 2019, 16, 1533-1543. [CrossRef]

9. Wang, Q.Q.; Gao, D.W.; Gao, C.T.; Wei, Q.F.; Cai, Y.B.; Xu, J.; Liu, X.Y.; Xu, Y. Removal of a Cationic Dye by Adsorption/Photodegradation Using Electrospun PAN/O-MMT Composite Nanofibrous Membranes Coated with $\mathrm{TiO}_{2}$. Int. J. Photoenergy 2012, 2012, 680419 .

10. Firouzjaei, M.D.; Afkhami, F.A.; Esfahani, M.R.; Turner, C.H.; Nejati, S. Experimental and molecular dynamics study on dye removal from water by a graphene oxide-copper-metal organic framework nanocomposite. J. Water Process Eng. 2020, $34,101180$. [CrossRef]

11. Khumalo, N.P.; Vilakati, G.D.; Mhlanga, S.D.; Kuvarega, A.T.; Mamba, B.B.; Li, J.X.; Dlamini, D.S. Dual-functional ultrafiltration nano-enabled PSf/PVA membrane for the removal of Congo red dye. J. Water Process Eng. 2019, 31, 100878. [CrossRef]

12. Minisy, I.M.; Zasonska, B.A.; Petrovsky, E.; Veverka, P.; Sedenkova, I.; Hromadkova, J.; Bober, P. Poly(p-phenylenediamine)/maghemite composite as highly effective adsorbent for anionic dy e removal. React. Funct. Polym. 2020, 146, 104436. [CrossRef]

13. Shittu, I.; Edathil, A.A.; Alsaeedi, A.; Al-Asheh, S.; Polychronopoulou, K.; Banat, F. Development of novel surfactant functionalized porous graphitic carbon as an efficient adsorbent for the removal of methylene blue dye from aqueous solutions. J. Water Process Eng. 2019, 28, 69-81. [CrossRef]

14. Singh, R.; Pal, D.; Mathur, A.; Singh, A.; Krishnan, M.A.; Chattopadhyay, S. An efficient pH sensitive hydrogel, with biocompatibility and high reusability for removal of methylene blue dye from a queous solution. React. Funct. Polym. 2019, 144, 104346. [CrossRef]

15. Wang, W.L.; Yang, X.X.; Yu, B.L.; Lin, J.M.; Cai, X.L. Synthesis of acid-resistant superparamagnetic conjugated porous polymers for fast and efficient removal of organic dye from aqueous media. React. Funct. Polym. 2020, 149, 104518. [CrossRef]

16. Crini, G. Non-conventional low-cost adsorbents for dye removal: A review. Bioresour. Technol. 2006, 97, 1061-1085. [CrossRef]

17. Gupta, V.K.; Suhas. Application of low-cost adsorbents for dye removal-A review. J. Environ. Manag. 2009, 90, 2313-2342. [CrossRef] [PubMed]

18. Royer, B.; Cardoso, N.F.; Lima, E.C.; Vaghetti, J.C.P.; Simon, N.M.; Calvete, T.; Veses, R.C. Applications of Brazilian pine-fruit shell in natural and carbonized forms as adsorbents to removal of methylene blue from aqueous solutions-Kinetic and equilibrium study. J. Hazard. Mater. 2009, 164, 1213-1222. [CrossRef]

19. Pacheco-Palencia, L.A.; Duncan, C.E.; Talcott, S.T. Phytochemical composition and thermal stability of two commercial acai species, Euterpe oleracea and Euter pe precatoria. Food Chem. 2009, 115, 1199-1205. [CrossRef]

20. Safa, Y.; Bhatti, H.N. Kinetic and thermodynamic modeling for the removal of Direct Red-31 and Direct Orange-26 dyes from aqueous solutions by rice husk. Desalination 2011, 272, 313-322. [CrossRef] 
21. Cardoso, N.F.; Lima, E.C.; Calvete, T.; Pinto, I.S.; Amavisca, C.V.; Fernandes, T.H.M.; Pinto, R.B.; Alencar, W.S. Application of Aqai Stalks As Biosorbents for the Removal of the Dyes Reactive Black 5 and Reactive Orange 16 from Aqueous Solution. J. Chem. Eng. Data 2011, 56, 1857-1868. [CrossRef]

22. Hasanzadeh, M.; Moghadam, B.H.; Abatari, M.H.M.; Haghi, A.K. On the production optimization of polyacrylonitrile electrospun nanofiber. Bulg. Chem. Commun. 2013, 45, 178-190.

23. Mahmoodi, N.M. Surface modification of magnetic nanoparticle and dye removal from ternary systems. J. Ind. Eng. Chem. 2015, 27, 251-259. [CrossRef]

24. Nasreen, S.A.; Sundarrajan, S.; Nizar, S.A.; Balamurugan, R.; Ramakrishna, S. Advancement in electrospun nanofibrous membranes modification and their application in water treatment. Membranes 2013, 3, 266-284. [CrossRef] [PubMed]

25. Swaminathan, S.; Muthumanickkam, A.; Imayathamizhan, N.M. An effective removal of methylene blue dye using polyacrylonitrile yarn waste/graphene oxide nanofibrous composite. Int. J. Environ. Sci. Technol. 2015, 12, 3499-3508. [CrossRef]

26. Xiao, J.; Wang, L.; Ran, J.R.; Zhao, J.Y.; Tao, M.L.; Zhang, W.Q. Highly selective removal of cationic dyes from water by acid-base regulated anionic functionalized polyacrylonitrile fiber: Fast adsorption, low detection limit, reusability. React. Funct. Polym. 2020, 146, 104394. [CrossRef]

27. Yazdi, M.G.; Ivanic, M.; Mohamed, A.; Uheida, A. Surface modified composite nanofibers for the removal of indigo carmine dye from polluted water. RSC Adv. 2018, 8, 24588-24598. [CrossRef]

28. Akbari, A.; Sheshdeh, F.J.; Jabbari, V. Novel nanofiberous membrane fabricated via electrospinning of wastage fuzzes of mechanized carpet used for dye removal of the carpet dyeing wastewater. J. Environ. Sci. Health Part A 2012, 47, 847-853. [CrossRef]

29. Li, C.; Lou, T.; Yan, X.; Long, Y.Z.; Cui, G.; Wang, X. Fabrication of pure chitosan nanofibrous membranes as effective absorbent for dye removal. Int. J. Biol. Macromol. 2018, 106, 768-774. [CrossRef] [PubMed]

30. Mahmoodi, N.M.; Mokhtari-Shourijeh, Z. Preparation of PVA-chitosan Blend Nanofiber and Its Dye Removal Ability from Colored Wastewater. Fiber Polym. 2015, 16, 1861-1869. [CrossRef]

31. Qi, F.F.; Qian, L.L.; Liu, J.J.; Li, X.Q.; Lu, L.G.; Xu, Q. A high-throughput nanofibers mat-based micro-solid phase extraction for the determination of cationic dyes in wastewater. J. Chromatogr. A 2016, 1460, 24-32. [CrossRef]

32. Yue, X.X.; Huang, J.W.; Jiang, F.; Li, H.; Chen, Y.Y. Synthesis and characterization of cellulose-based adsorbent for removal of anionic and cationic dyes. J. Eng. Fiber Fabr. 2019, 14, 1558925019828194. [CrossRef]

33. Ashori, A.; Cordeiro, N.; Faria, M.; Hamzeh, Y. Effect of chitosan and cationic starch on the surface chemistry properties of bagasse paper. Int. J. Biol. Macromol. 2013, 58, 343-348. [CrossRef]

34. Wu, F.C.; Tseng, R.L.; Juang, R.S. Kinetic modeling of liquid-phase adsorption of reactive dyes and metal ions on chitosan. Water Res. 2001, 35, 613-618. [CrossRef]

35. Crini, G.; Badot, P.M. Application of chitosan, a natural aminopolysaccharide, for dye removal from aqueous solutions by adsorption processes using batch studies: A review of recent literature. Prog. Polym. Sci. 2008, 33, 399-447. [CrossRef]

36. Mine, Y. Recent Advances in the Understanding of Egg-White Protein Functionality. Trends Food Sci. Technol. 1995, 6, 225-232. [CrossRef]

37. Ng, I.S.; Song, C.P.; Ooi, C.W.; Tey, B.T.; Lee, Y.H.; Chang, Y.K. Purification of lysozyme from chicken egg white using nanofiber membrane immobilized with Reactive Orange 4 dye. Int. J. Biol. Macromol. 2019, 134, 458-468. [CrossRef]

38. Wang, S.S.; Yang, S.M.; Hsin, A.; Chang, Y.K. Dye-Affinity Nanofibrous Membrane for Adsorption of Lysozyme: Preparation and Performance Evaluation. Food Technol. Biotechnol. 2018, 56, 40-50. [CrossRef]

39. Abeyrathne, E.D.N.S.; Lee, H.Y.; Ahn, D.U. Egg white proteins and their potential use in food processing or as nutraceutical and pharmaceutical agents-A review. Poult. Sci. 2013, 92, 3292-3299. [CrossRef] [PubMed]

40. Ma, Z.W.; Kotaki, M.; Ramarkrishna, S. Surface modified nonwoven polysulphone (PSU) fiber mesh by electrospinning: A novel affinity membrane. J. Membr. Sci. 2006, 272, 179-187. [CrossRef]

41. Yang, M.C.; Lin, W.C. Surface modification and blood compatibility of polyacrylonitrile membrane with immobilized chitosanheparin conjugate. J. Polym. Res. 2002, 9, 201-206. [CrossRef]

42. Huong, D.T.M.; Chai, W.S.; Show, P.L.; Lin, Y.L.; Chiu, C.Y.; Tsai, S.L.; Chang, Y.K. Removal of cationic dye waste by nanofiber membrane immobilized with waste proteins. Int. J. Biol. Macromol. 2020, 164, 3873-3884. [CrossRef]

43. Pakalapati, H.; Show, P.L.; Chang, J.H.; Liu, B.L.; Chang, Y.K. Removal of dye waste by weak cation-exchange nanofiber membrane immobilized with waste egg white proteins. Int. J. Biol. Macromol. 2020, 165, 2494-2507. [CrossRef] [PubMed]

44. Shimada, I.; Takahagi, T.; Fukuhara, M.; Morita, K.; Ishitani, A. Ft-Ir Study of the Stabilization Reaction of Polyacrylonitrile in the Production of Carbon-Fibers. J. Polym. Sci. Part A Polym. Chem. 1986, 24, 1989-1995. [CrossRef]

45. Travlou, N.A.; Kyzas, G.Z.; Lazaridis, N.K.; Deliyanni, E.A. Functionalization of graphite oxide with magnetic chitosan for the preparation of a nanocomposite dye adsorbent. Langmuir 2013, 29, 1657-1668. [CrossRef] [PubMed]

46. Sharma, S.; Agarwal, G.P. Interactions of proteins with immobilized metal ions: A comparative analysis using various isotherm models. Anal. Biochem. 2001, 288, 126-140. [CrossRef]

47. Guo, L.; Li, G.Y.; Liu, J.S.; Ma, S.M.; Zhang, J.F. Kinetic and Equilibrium Studies on Adsorptive Removal of Toluidine Blue by Water-Insoluble Starch Sulfate. J. Chem. Eng. Data 2011, 56, 1875-1881. [CrossRef]

48. Gupta, V.K.; Mittal, A.; Gajbe, V.; Mittal, J. Removal and recovery of the hazardous azo dye acid orange 7 through adsorption over waste materials: Bottom ash and de-oiled soya. Ind. Eng. Chem. Res. 2006, 45, 1446-1453. [CrossRef] 
49. Hamzeh, Y.; Ashori, A.; Azadeh, E.; Abdulkhani, A. Removal of Acid Orange 7 and Remazol Black 5 reactive dyes from aqueous solutions using a novel biosorbent. Mater. Sci. Eng. C 2012, 32, 1394-1400. [CrossRef]

50. Lim, C.K.; Bay, H.H.; Neoh, C.H.; Aris, A.; Majid, Z.A.; Ibrahim, Z. Application of zeolite-activated carbon macrocomposite for the adsorption of Acid Orange 7: Isotherm, kinetic and thermodynamic studies. Environ. Sci. Pollut. Res. 2013, 20, $7243-7255$. [CrossRef]

51. Padmesh, T.V.N.; Vijayaraghavan, K.; Sekaran, G.; Velan, M. Application of Azolla rongpong on biosorption of acid red 88, acid green 3, acid orange 7 and acid blue 15 from synthetic solutions. Chem. Eng. J. 2006, 122, 55-63. [CrossRef]

52. Silva, J.P.; Sousa, S.; Rodrigues, J.; Antunes, H.; Porter, J.J.; Goncalves, I.; Ferreira-Dias, S. Adsorption of acid orange 7 dye in aqueous solutions by spent brewery grains. Sep. Purif. Technol. 2004, 40, 309-315. [CrossRef]

53. Xu, Y.; Li, X.; Xiang, H.F.; Zhang, Q.Q.; Wang, X.X.; Yu, M.; Hao, L.Y.; Long, Y.Z. Large-Scale Preparation of Polymer Nanofibers for Air Filtration by a New Multineedle Electrospinning Device. J. Nanomater. 2020, 2020, 4965438. [CrossRef]

54. Zhu, F.; Zheng, Y.M.; Zhang, B.G.; Dai, Y.R. A critical review on the electrospun nanofibrous membranes for the adsorption of heavy metals in water treatment. J. Hazard. Mater. 2021, 401, 123608. [CrossRef] [PubMed]

55. Saleh, M.; Sharafoddinzadeh, D.; Mokhtari, F.; Esfandarani, M.S.; Karami, S. Electrospun nanofibers for efficient adsorption of heavy metals from water and wastewater. Clean Technol. Recycl. 2021,1,1-33. [CrossRef]

56. Mukund, M.; Siddharth, S.; Mayank, S.; Kumar, G.C.; Shanthi, V. Study of operational parameters and kinetics of biosorption of Acid Orange 7 by untreated sugarcane bagasse. J. Chem. Pharm. Res. 2013, 5, 523-531.

57. Izadyar, S.; Rahimi, M. Use of beech wood sawdust for adsorption of textile dyes. Pak. J. Biol. Sci. 2007, 10, 287-293. [CrossRef]

58. Seema, J.; Garg, V.K.; Jyoti, S.; Kadirvelu, K. Removal of toulidine Blue O Dye from aqueous solution by silica-iron oxide nanoparticle. Mater. Focus 2018, 7, 140-146. 